\title{
A Comparison of the Influence of Kraft Lignin and the Kraft Lignin/Silica System as Cell Carriers on the Stability and Efficiency of the Anaerobic Digestion Process
}

\author{
Agnieszka A. Pilarska ${ }^{1, *(1)}$, Agnieszka Wolna-Maruwka ${ }^{2}$, Alicja Niewiadomska ${ }^{2}{ }^{\mathbb{D}}$, \\ Krzysztof Pilarski ${ }^{3}$ and Artur Olesienkiewicz ${ }^{4}$ \\ 1 Department of Plant-Derived Food Technology, Poznań University of Life Sciences, ul. Wojska Polskiego 31, \\ 60-624 Poznań, Poland \\ 2 Department of General and Environmental Microbiology, Poznań University of Life Sciences, \\ ul. Szydłowska 50, 60-656 Poznań, Poland; amaruwka@up.poznan.pl (A.W.-M.); \\ alicja.niewiadomska@up.poznan.pl (A.N.) \\ 3 Department of Biosystems Engineering, Poznań University of Life Sciences, ul. Wojska Polskiego 50, \\ 60-627 Poznań, Poland; pilarski@up.poznan.pl \\ 4 Polbiotech Laboratorium Sp. z o.o., Poznań Science and Technology Park, ul. Rubież 46, 61-612 Poznań, \\ Poland; artur.olesienkiewicz@polbiotech.pl \\ * Correspondence: pilarska@up.poznan.pl; Tel.: +48-61-848-73-08
}

Received: 25 September 2020; Accepted: 3 November 2020; Published: 6 November 2020

\begin{abstract}
This study compares the effects of pure kraft lignin and the kraft lignin/silica system (1:4 by weight). The comparative analysis of the physicochemical properties of both carriers showed that the kraft lignin/silica system was characterised by better properties. The experiment conducted in the study involved continuous anaerobic digestion under mesophilic conditions. Three samples were degraded in the following order: (i) sewage sludge (SS), (ii) SS with the addition of kraft lignin, and (iii) SS with the addition of the kraft lignin/silica system. A quantitative analysis of the digestate samples was carried out by means of in situ fluorescence. It showed more intense proliferation of microorganisms in the SS + kraft lignin/silica variant than in the sample with pure kraft lignin. The highest amount of biogas was obtained in the SS + kraft lignin/silica variant $\left(689 \mathrm{~m}^{3} \mathrm{Mg}^{-1} \mathrm{VS}\right.$, including $413 \mathrm{~m}^{3} \mathrm{Mg}^{-1}$ VS of methane; VS-volatile solids). There were comparable amounts of biogas in the SS variant (526 m $\mathrm{mg}^{-1} \mathrm{VS}$ of biogas, including $51 \%$ of methane) and the SS + kraft lignin variant ( $586 \mathrm{~m}^{3} \mathrm{Mg}^{-1} \mathrm{VS}$ of biogas, including $54 \%$ of methane). The research clearly showed that the material with a high share of silica was an effective cell carrier.
\end{abstract}

Keywords: kraft lignin; silica; microbial carriers; anaerobic digestion; process efficiency

\section{Introduction}

Good condition of the bacterial flora is a fundamental factor guaranteeing the high efficiency of biogas/methane production in the anaerobic digestion (AD) process. The activity of methanogens and other mixed cultures can be improved by their immobilisation with the right medium, which will ensure the intensification of biochemical changes [1]. Basically, interactions between microorganisms and material result in the formation of a tight and stable biofilm, which naturally becomes a more active catalyst of bioconversion processes. According to data in reference publications, so far, several types of microbiological carriers have been tested in the AD process. Natural zeolites have been tested most often due to their favourable adhesive properties [2,3]. However, there is increasing interest 
in other natural additives, which are environmentally friendly, available, biocompatible, and with defined physicochemical properties, such as thermal stability, porous structure and well-developed specific surface $[4,5]$.

Lignin is a material with the properties listed above. It is a natural polymer, a basic component of wood, with a porous structure, is resistant to hydrolytic enzymes and is thermally stable [6]. Lignin is characterised by a well-developed specific surface area, absorbency, thermoplasticity, and specific structure. The low cost, environmental friendliness, and other valuable properties contributed to the development of innovative 'green' applications of this material, which is used as a filler in a wide range of polymers, as a carrier or component of a carrier for enzyme immobilisation, and as a material for the construction of electrochemical sensors, detectors, and innovative lithium-ion batteries. Due to the presence of numerous functional groups in the lignin molecule, especially carboxylic and phenolic groups on the lignin surface, it could be a potential biosorbent for hazardous metal ions [5-8]. As shown in recent reports, there is advanced research on the selective conversion (depolymerisation, digestion) of lignocellulosic biomass into bio-based organic mono-aromatic compounds by means of various solvents, including deep eutectic solvents (DES) and ethanol $[9,10]$. Due to the high thermal stability of kraft lignin, it is also used as a flame-retardant material [11], e.g., in briquettes produced from sugarcane bagasse. Kraft lignin has a potential to be used as both a binder in compressed products and an additive for the production of bio-oil with valuable phenolic compounds [12]. Innovative materials synthesised with lignin include Fe-lignin composites, which are high-activity catalysts [13]. As shown in the latest reports, there is advanced research on the hydrogenolysis and hydrodeoxygenation of lignin dimer model compounds, particularly the cleavage of $\mathrm{C}-\mathrm{C}$ and ether bonds, by means of selective catalysts [14]. These examples of the latest research and applications of kraft lignin show that this material has high potential and there is growing scientific interest in it.

Lignin, which is part of lignocellulosic biomass, is hardly decomposed in the digestion process. Therefore, digestate, which is a co-product of anaerobic digestion, is a lignin-rich substrate, which can be used as a fertiliser or composted [15]. It is noteworthy that as a precursor substance of humic acid, lignin is a basic chemical compound affecting the formation of soil organic matter, its structure and bioactivity [16]. The author of this study described this material in detail and tested it in mono-digestion and co-digestion of organic waste [17-19].

Silica is a mesoporous material with a particularly well-developed specific surface area and a wide range of other desirable properties for cell carriers. It is used in various branches of science and industry. Due to the specific physicochemical and electrochemical properties of silicas, they are used in various industries, including the pharmaceutical, cosmetic, chemical, paper, varnish, and electrochemical industries $[20,21]$. The authors of other studies noticed that the integration of lignin and silica resulted in the formation of a material with strong adsorption of dyes, harmful organic compounds, and heavy metals, as well as enzymes and natural macromolecules [22-25]. The ability of silica to adsorb proteins is commonly used in biomedicine. The porosity of silica does not promote protein adsorption, but it improves the deposition of low-molecular weight protein fractions due to the size-exclusion effect related to the pore diameter [26]. When lignin, which has strong adsorptive properties and high resistance to degradation, is combined with porous and biocompatible silica, an effective carrier and cell activator for anaerobic digestion may be formed. Dai et al. (2017) and Chen et al. (2020) observed the effect of micron silica particles on the decomposition of organic matter in wastewater $[27,28]$.

This study compares the effect of pure kraft lignin and the kraft lignin/silica system (1:4 by weight) as cell carriers in the continuous mesophilic anaerobic digestion of sewage sludge. The physicochemical properties of both carriers were discussed and the cellular biomass in the Bacillus amyloliquefaciens culture was measured. The degree of proliferation of microorganisms and changes in the dehydrogenase activity (DHA) during the decomposition of subsequent sewage sludge (SS) samples were assessed. The digestate was successively collected to verify the concentration of heavy metals, the values of the parameters that determine the stability of the process, i.e., $\mathrm{pH}$, volatile fatty acids-to-total alkalinity 
ratio (VFA/TA ratio), $\mathrm{N}-\mathrm{HH}_{4}{ }^{+}$. Finally, the biogas efficiency of sewage sludge in each of the three samples was measured.

\section{Materials and Methods}

\subsection{Substrate and Carriers}

Raw sewage sludge from a municipal sewage treatment plant was used as a substrate in the experiment. Digested sewage sludge was collected from a biogas plant belonging to the same company and used as an inoculum. Kraft lignin (lignin, alkali) and silica (silicon dioxide, powder) — both from Sigma-Aldrich Chemie GmbH, Taufkirchen, Germany, were used as carriers.

\subsection{Preparation of Carriers}

The carriers were prepared as two systems: (i) kraft lignin $\left(20 \mathrm{~g} \mathrm{~L}^{-1}\right)$ and (ii) kraft lignin/silica (1:4) — kraft lignin $\left(4 \mathrm{~g} \mathrm{~L}^{-1}\right)$ and silica $\left(16 \mathrm{~g} \mathrm{~L}^{-1}\right)$. These quantities were based on data provided in reference publications [29].

The hybrid kraft lignin/silica system was generated by mechanical grinding and simultaneous mixing of the input components with a ball mill (PULVERISETTE 23, FRITSCH Bakery Technologies GmbH \& Co. KG, Markt Einersheim, Germany). The carriers were first washed with phosphate-buffered saline (PBS) and then with sterile distilled water. Next, they were dried at $70{ }^{\circ} \mathrm{C}$ (SL 115 dryer, POL-EKO-APARATURA, Wodzisław Śląski, Poland) until a constant (initial) weight was obtained. Then, they were applied to the digester under anaerobic conditions.

\subsection{Bacillus Amyloliquefaciens Cell Biomass}

The biomass of bacterial cells in the culture with the carriers tested in the experiment was measured with the weight method (the authors' original procedure). First, the carriers (kraft lignin and kraft lignin/silica) were rinsed with a PBS solution. Then they were rinsed with sterile distilled water and dried at $70{ }^{\circ} \mathrm{C}$ to obtain a constant initial weight. The carriers were prepared at amounts calculated for $100 \mathrm{~mL}$ (see Section 2.2) and combined with $0.6 \mathrm{~g}$ of glucose and $1.3 \mathrm{~g}$ of regular broth in a flask. Next, the content was supplemented with distilled water to a volume of $100 \mathrm{~mL}$ and sterilised in an autoclave for $40 \mathrm{~min}$ at $110^{\circ} \mathrm{C}$. The substrate prepared in this way was inoculated with the autochthonous Bacillus amyloliquefaciens strain, which had been isolated from the digested sewage sludge. The inoculated samples (except for the control samples) were incubated at $24^{\circ} \mathrm{C}$ for 5 days and shaken at $75 \mathrm{rpm}$ in a Compact Shaker KS 15 B (Edmund Bühler GmbH). After 5 days, the cultures, including the control samples, were centrifuged for $15 \mathrm{~min}$ at $15,000 \mathrm{rpm}$ and $4{ }^{\circ} \mathrm{C}$ in a Universal $16 \mathrm{R}$ centrifuge (Hettich). The biomass of bacterial cells cultured in the medium with the carriers was calculated as the difference between the weight $(\mathrm{g})$ of the uninoculated medium and the medium inoculated with the autochthonous Bacillus amyloliquefaciens strain. The analysis was triplicated for each carrier and the result was averaged. The differences in the bacterial biomass were taken into account to determine the standard deviation.

\subsection{Experimental Set-Up of Continuous Systems}

\subsubsection{Structure and Operation of Digester}

A glass bioreactor with a working volume of $2 \mathrm{dm}^{3}$ (see Figure 1, symbol NO.2), equipped with a two-level anchor propeller driven by a variable-speed stirrer (11) (Heidolph Instruments GmbH \& Co. KG, Schwabach, Germany), was used in the study. Every 57 min, the stirrer turned on automatically and worked for $3 \mathrm{~min}$. The propeller axis passed through a gas-tight bearing installed in the top cover with three stub pipes $(3,4,5)$. Two of them, marked as no. 4 and 5 in Figure 1 , were used to discharge the biogas to the eudiometer (6) and to collect biogas samples for analyses. One stub pipe, with a larger diameter, was used for dosing new portions of the substrate and process 
additives to the bioreactor (3). At the bottom of the bioreactor tank there was a bottom stub pipe with a ball valve, which was used to collect samples of the digested mass for tests (9). During digestion, the bioreactor was immersed in a $15 \mathrm{~L}$ water bath (1), heated by a thermoregulator and a $350 \mathrm{~W}$ electric heater. There was a circulation pump with a capacity of about $600 \mathrm{~L} \mathrm{~h}^{-1}$ (10) to maintain a constant temperature of water in the entire bath. The process was carried out under mesophilic conditions, i.e., $37-38^{\circ} \mathrm{C}$.

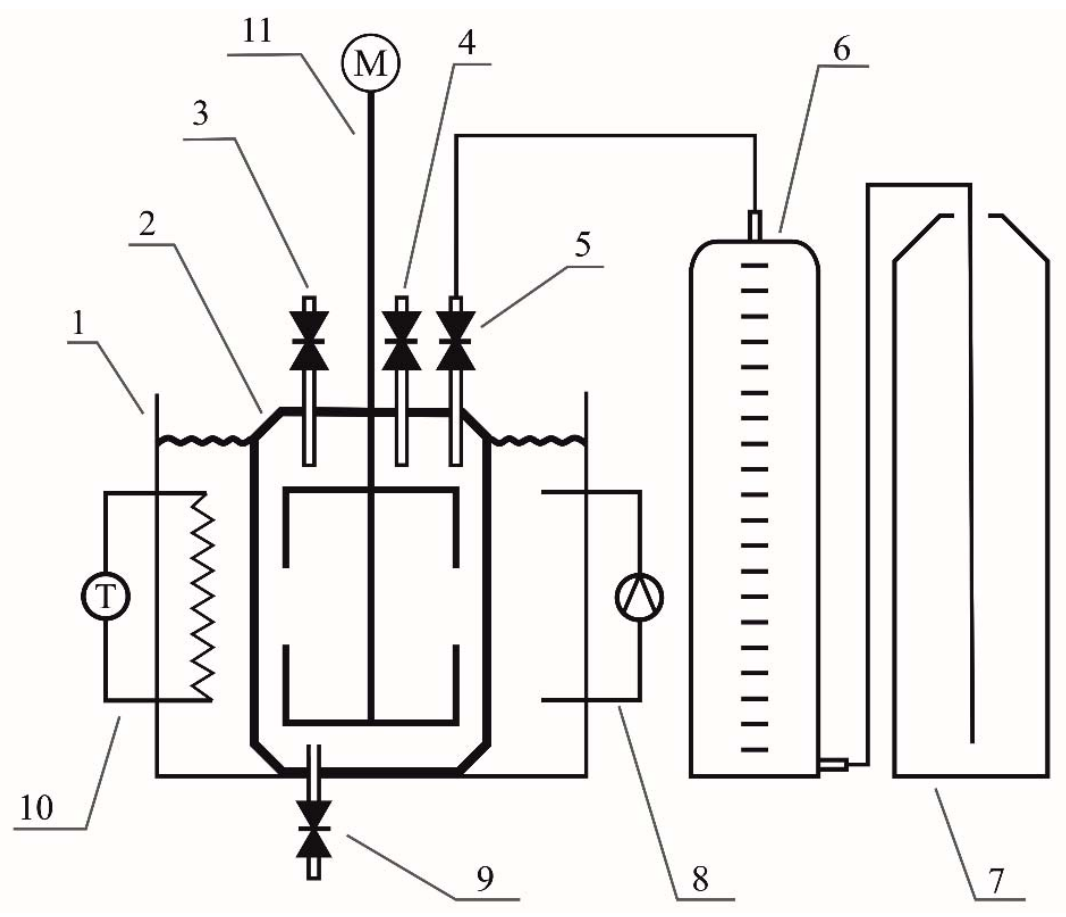

Figure 1. The digester used in the experiment for the production of biogas in the continuous mesophilic anaerobic digestion process; 1-water bath; 2-bioreactor; 3-stub pipe for dosing substrates and process additives; 4 -stub pipe for sampling/biogas composition analysis; 5-stub pipe for discharging biogas to eudiometer; 6-eudiometer; 7-collection/expansion vessel; 8 -circulation of water in water bath with pump; 9 -stub pipe with drain valve for sampling of digested biomass; 10—thermoregulator with electric heater; 11-double anchor agitator with drive and speed regulation.

The biogas generated in the bioreactor was collected and measured in a eudiometer with a capacity of $5 \mathrm{dm}^{3}$ (6). The gas entered through the upper end of the eudiometer exerted pressure on the liquid inside the eudiometer and pushed it through the lower end to the expansion tank (7) located above the eudiometer. The expansion tank and the eudiometer constituted communicating vessels. The eudiometer was filled with a solution composed of sulphuric acid and sodium carbonate, and a methyl orange dye for better contrast. This composition and low $\mathrm{pH}$ guaranteed that the biogas components did not dissolve in the solution and thus they did not affect the result of analysis of the biogas composition. The analyses of biogas/methane production were carried out according to the German standard DIN 38 414-S8 [30].

\subsubsection{Anaerobic Digestion}

The digester worked in a continuous mode. There were three stages of the experiment. In the first stage, the bioreactor was filled with digested sewage sludge, which was used as an inoculum. When the temperature stabilised $\left(37-38^{\circ} \mathrm{C}\right)$, raw sewage sludge was dosed as the substrate. In industrial production, it is used as a feed for a biogas plant in a sewage treatment plant. The dose of the substrate was selected so that it was the equivalent of organic loading rate (OLR): about $1 \mathrm{~kg} \mathrm{VS}\left(\mathrm{m}^{3} \cdot \mathrm{d}\right)^{-1}$ (VS-volatile solids), at a hydraulic retention time (HRT) of about 40 days. 
The course of the second stage of the digestion process was analogous to the first stage, but an additive of kraft lignin was dosed together with the substrate into the digester. The bacterial cell carrier was prepared (see Section 2.2) and fed over five consecutive days at an adequate dose to obtain a carrier concentration of $20 \mathrm{~g} \mathrm{~L}^{-1}$. During the next eight days of the process kraft lignin was added (about $2 \mathrm{~g} \mathrm{day}^{-1}$ ) to each batch of the substrate at an adequate amount so that its concentration in the digester would theoretically remain constant, i.e., $20 \mathrm{~g} \mathrm{~L}^{-1}$. The general assumption of maintaining a constant concentration of lignin was that it did not degrade and a new portion of lignin would supplement the amount collected from the bioreactor together with the excess digestate. In this stage, a lower OLR was used, i.e., $0.65 \mathrm{~kg} \mathrm{VS}\left(\mathrm{m}^{3} \cdot \mathrm{d}\right)^{-1}$. This stage also lasted 14 days.

In the third stage of the process (another 14 days), raw sewage sludge was dosed together with a mixture of $25 \%$ kraft lignin and $75 \%$ silica. During the first five days, the amount of the mixture was dosed to ensure that the concentration was close to $20 \mathrm{~g} \mathrm{~L}^{-1}$. On the following days, the doses of the mixture were lower, so as to maintain a constant concentration of the carrier in the bioreactor. Like in the second stage, the OLR was maintained at $0.65 \mathrm{~kg} \mathrm{VS}\left(\mathrm{m}^{3} \cdot \mathrm{d}\right)^{-1}$.

Each day, samples collected from the bioreactor were analysed for $\mathrm{pH}$ and the composition of biogas. The following values were also measured at specific terms of each stage of the study: total solids, volatile solids, ammonium nitrogen concentration, volatile fatty acids/total alkalinity (VFA/TA) ratio and the concentrations of heavy metals, such as $\mathrm{Zn}$ and $\mathrm{Pb}$. Apart from the physicochemical analyses, the digestate samples were also analysed microbiologically and biochemically.

\subsection{Analytical Methods}

\subsubsection{Physicochemical Analysis of Substrate, Digestate and Biogas Samples}

The $\mathrm{pH}$ of the sewage sludge and the digestion mixture was measured with the potentiometric method (PN-EN 12176:2004, EN 15933:2012) by means of an Elmetron CP-215 (ELMETRON, Zabrze, Poland). The total solids content was measured with the gravimetric method by drying to a constant weight at $105^{\circ} \mathrm{C}$ (PN-EN 12880:2004, EN 15934:2012). The volatile solids content (loss on ignition) was also measured with the weight method by burning a dry sample (obtained after

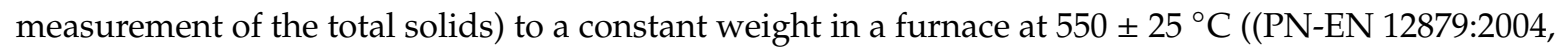
EN 15935:2012), MS Spectrum PAF 110/6 furnace, MS Spectrum, Warsaw, Poland).

The ammonium nitrogen content in the substrate and in the digestate samples was measured by distillation and titration ((PN-ISO 5664, ISO 5664), Büchi K-360 distiller, Büchi Labortechnik AG, Zurich, Switzerland). The weighed sample was heated with water vapour in the presence of magnesium oxide. The distillate was collected into a $2 \%$ boric acid solution with a Tashiro indicator. The distilled ammonium nitrogen was titrated to colour change with a digital burette and $0.1 \mathrm{n} \mathrm{HCl}$.

The VFA/TA ratio of the digestate mixture samples was measured by titration in a dedicated HACH LANGE titrator (Wrocław, Poland). The samples were diluted with $0.1 \mathrm{n} \mathrm{H}_{2} \mathrm{SO}_{4}\left(0.05 \mathrm{~mol} / \mathrm{dm}^{3}\right)$ and titrated potentiometrically so as to obtain two $\mathrm{pH}$ values- 5.0 and 4.4. The obtained volumes were automatically converted for the values of VFA $\left(\mathrm{mg} \mathrm{CH}_{3} \mathrm{COOH} / \mathrm{L}\right), \mathrm{TA}(\mathrm{mg} / \mathrm{L} \mathrm{CaCO} 3)$ and VFA/TA ratio. The concentration of volatile fatty acids was measured by gas chromatography with a flame ionisation detector (FID). The VFAs were extracted into tetramethyl ethyl ether and injected onto an Agilent CP-FFAP CB $25 \mathrm{~m} \times 0.32 \mathrm{~mm}$ column, at a temperature gradient of $100-250{ }^{\circ} \mathrm{C}$ for $20 \mathrm{~min}$ [31].

The lead and zinc content was measured by mass spectrometry with ionisation in inductively coupled plasma ICP-MS for the following ranges: zinc-0.050-30.0 mg/L; lead-0.010-10.0 mg/L (PN-EN ISO 17072-1: 2011), ICP-MS Agilent 7800 spectrometer (Agilent Technologies, Santa Clara, CA, USA). The concentrations of both metals were measured on the supernatant and sediment fractions obtained after $5 \mathrm{~min}$ centrifugation of $100 \mathrm{~mL}$ of the digestate sample collected from the bioreactor (Eppendorf Centrifuge 5702) at a speed of 3000 $\times g$ (4400 rpm). 
The composition of the biogas accumulated in the eudiometer was analysed by passing it through the measuring cells in a BIOGAS 5000 analyser (Geotechnical Instruments Ltd., Coventry UK). The percentages of $\mathrm{CH}_{4}, \mathrm{CO}_{2}, \mathrm{O}_{2}$ and $\mathrm{H}_{2} \mathrm{~S}$ by volume were measured.

\subsubsection{Physicochemical Characteristics of Carrier Materials}

Various physicochemical properties of kraft lignin and the kraft lignin/silica system, as well as their morphological dispersion were compared and analysed. A Zetasizer apparatus with a $4 \mathrm{~mW}$ helium/neon laser (Zetasizer Nano ZS, Malvern Instruments Ltd., Malvern/Worcestershire, UK) was used to measure particles sized $0.6-6000 \mathrm{~nm}$. The particles were measured by the apparatus by non-invasive backscattering (NIBS). All samples were isolated in isopropanol before analysis using mild sonication, and measurements were performed at $25^{\circ} \mathrm{C}$. The FEI Quanta 250 FEG scanning electron microscope (Thermo Fisher Scientific, Waltham, MA, USA), which operates in a low vacuum mode at $70 \mathrm{~Pa}$ and an accelerating voltage of $10 \mathrm{kV}$, was used to record images of the morphology and microstructure of the kraft lignin and kraft lignin/silica materials, which were then examined and analysed. The samples were coated with Au for $5 \mathrm{~s}$ with a Balzers PV205P coater (Oerlikon Balzers Coating SA, Balzers, Switzerland) before conducting the examination.

An ASAP 2420 instrument (Micromeritics Instrument Co., Norcross, GA, USA) was used in order to measure surface area $\left(\mathrm{A}_{\mathrm{BET}}\right)$, total volume $\left(\mathrm{V}_{\mathrm{p}}\right)$ and mean size $\left(\mathrm{S}_{\mathrm{p}}\right)$ of pores, as well as the porous structure parameters, nitrogen adsorption/desorption isotherms at $77 \mathrm{~K}$. After measuring these parameters, degassing was carried out at $90^{\circ} \mathrm{C}$ using a vacuum. The Brunauer-Emmett-Teller (BET) model was used to calculate the specific surface area (SSA), which was also applied for the linear part of adsorption isotherm $\left(0.05<\mathrm{P}_{0}<0.25\right)$. Meanwhile, the Barrett-Joyner-Halenda (BJH) method was used to measure and calculate the mean pore size and volume.

The samples, which were in tablet form, were prepared by pressing a mixture at a pressure of approximately $10 \mathrm{MPa}$ of anhydrous $\mathrm{KBr}$ (approximately $0.25 \mathrm{~g}$ ) and $1 \mathrm{mg}$ of the tested substance in a special steel ring. Fourier transform infrared spectroscopy (FTIR) measurements were made at room temperature on a Vertex 70 spectrophotometer (Bruker Optik GmbH, Leipzig, Germany). FTIR spectra were obtained at a transmission mode between 400 and $4000 \mathrm{~cm}^{-1}$, and the sample analysis was made at a resolution of $0.5 \mathrm{~cm}^{-1}$ [18]. In order to analyse the chemical composition of the samples, a FLASH 2000 elemental analyser (Thermo Fisher Scientific, Waltham, MA, USA) was used. The analysis from this elemental analyser was based on the dynamic combustion technique. Approximately $2-4 \mathrm{mg}$ of the samples were placed into the reactor combined with a precisely defined portion of oxygen by means of an autosampler. Combustion was performed at $900-1000^{\circ} \mathrm{C}$. Once the combustion process was completed, the flue gases were transported in a helium flow to another reactor furnace, which was filled with copper. The gases were then transported through a water trap into the chromatography column. Once separation of the gases was complete, a thermal conductivity detector was used to detect these separated gases.

Kraft lignin and the kraft lignin/silica system were also tested in a nitrous environment for thermal stability using a TGA 4000 thermogravimetric analyser (PerkinElmer, Waltham, MA, USA). The samples were heated in nitrogen from 25 to $995^{\circ} \mathrm{C}$ at a flow rate of $20 \mathrm{~mL} \mathrm{~min}{ }^{-1}$ and were kept at $995^{\circ} \mathrm{C}$ for 1 min before cooling.

\subsubsection{Microbiological and Biochemical Analysis of Digestate}

The total count of bacteria from six samples collected during the digestion process was measured by means of the modified fluorescent in situ hybridisation (FISH) method under a fluorescent microscope (Carl Zeiss AG, Oberkochen, Germany) according to Amann et al. (1990) [32]. Microbiological analyses were conducted at five various terms of the experiment. The first analysis was conducted on the 2nd day of the experiment, the second on the 4th day of the experiment, the third on the 8th day of the experiment, the fourth on the 10th day of the experiment and lastly the fifth on the 14th day of the experiment. Approximately $0.01 \mathrm{~mL}$ of the fermented sludge was placed onto the 
surface of slides and placed into a breeding chamber. Subsequently, the samples were fixed with a 4\% PFA solution (paraformaldehyde), washed in a phosphate buffer solution (PBS) three times, and lastly $0.5 \%$ of Triton solution was added. The samples were then washed again three times in PBS and placed in alcohol series of $70 \%, 80 \%$ and $96 \%$. Lastly, $70 \%$ of a formamide solution was added and the genetic probe EUB $_{338}$ GCT GCC TCC CGT AGGAGT (Amann et al. 2019) was applied at a concentration of $25 \mathrm{ng} \mu \mathrm{L}^{-1}$ [33]. The samples were stained with a Cy5 fluorescent dye and suspended in a solution consisting of $5 \mathrm{M} \mathrm{NaCl}, 1 \mathrm{M}$ Tris/HCL, $25 \%$ formamide, $10 \%$ SDS and $\mathrm{ddH}_{2} \mathrm{O}$. Once this process was complete, the samples were incubated at $37^{\circ} \mathrm{C}$ for $24 \mathrm{~h}$ in complete darkness. A fluorescence microscope equipped with an AxioCam MRc5 colour digital camera was used to analyse and capture images of the prepared samples. The images were analysed by the AxioVision 4.8 software (AxioVision LE 4.8 2.0, Carl Zeiss Microscopy, LLC, White Plains, NY, USA) [18]. The digestate samples underwent biochemical analysis by means of the spectrophotometric method and dehydrogenase activity was measured by means of the method developed by [28], with some modifications. Samples of approximately $5 \mathrm{~mL}$ were incubated at $30^{\circ} \mathrm{C}$, at a pH of 7.4 for $24 \mathrm{~h}$ with 2,3,5-triphenyltetrazolium chloride (TTC). Triphenylformazan (TPF) was yielded, extracted with $96 \%$ ethanol, and lastly measured spectrophotometrically at $285 \mathrm{~nm}$. The dehydrogenase activity was expressed as $\mu \mathrm{mol} \mathrm{TPF} \mathrm{g}{ }^{-1} \mathrm{DM}$ of waste $24 \mathrm{~h}^{-1}$ (Camiña et al., 1998) [34].

\subsubsection{Statistical Analyses}

Statistical analyses were conducted using the Statistica 13.3 software (StatSoft Inc. 2013, Tulsa, OK, USA). The significance of the variation in the count of groups of bacteria and the soil enzymatic activity was determined by two-way analysis of variance. Tukey's test was used to identify homogenous subsets of means at a significance level of $p=0.05$. Stepwise regression was used to determine the optimal set of variables for a given characteristic of the bacteria and dehydrogenase activity. On the basis of the highest F-value for the model and the significance of all the independent variables, the best regression model was selected. Principal component analysis (PCA) was used to illustrate the dependence between the biomass and activity of microorganisms as well as the chemical properties in the digestion process of different types of waste.

\section{Results and Discussion}

\subsection{Characterisation of Substrate and Inoculum}

The $\mathrm{pH}$ of both the raw sewage sludge, used as the substrate in the experiment, and the inoculum, i.e., digested sewage sludge (both from the same company), was close to neutral (see Table 1). The materials were characterised by low TS content (4.6\% in the SS and $2.4 \%$ in the inoculum), but a high content of organic matter $(81.4 \%$ and $65.7 \% \mathrm{TS}$, respectively). Both types of sewage sludge were used in earlier experiments conducted by the authors, where they were characterised in detail, especially in the study [35], which explained the mechanism of generation of high buffer capacity (ensured by alkalinity) of digested sewage sludge as a result of changes in the elemental nitrogen and the accompanying release of carbonates and bicarbonates. The values of other key physicochemical parameters of the tested SS, including the content of light and heavy metals, were presented in subsequent studies $[17,18,36]$.

Table 1. Selected physicochemical parameters of the substrate and inoculum.

\begin{tabular}{ccccc}
\hline Material & $\begin{array}{c}\mathrm{pH} \\
(-)\end{array}$ & $\begin{array}{c}\text { TS } \\
(\mathbf{w t} \%)\end{array}$ & $\begin{array}{c}\text { VS } \\
(\mathbf{w t} \text { \% } \mathbf{~ T S})\end{array}$ & $\begin{array}{c}\text { TKN } \\
(\mathbf{w t} \text { \% } \mathbf{T S})\end{array}$ \\
\hline SS & 6.83 & 4.6 & 81.4 & 0.33 \\
\hline SS-sewage sludge, TS-total solids, VS-volatile solids, TKN-total Kjeldahl nitrogen.
\end{tabular}




\subsection{Characterisation of Carrier Materials}

\subsubsection{Dispersive and Morphological Properties}

Figure 2 shows the particle size distributions by volume of kraft lignin and the kraft lignin/silica system (1:4 ratio by weight). The narrow band for kraft lignin indicates a small range of particle diameters and the monodisperse nature of the sample-the highest share, i.e., $31.0 \%$ was noted for particles with a diameter of $712 \mathrm{~nm}$ [18]. The kraft lignin/silica system was characterised by a wider band, with the highest share $(17 \%)$ of particles with a diameter of $105.7 \mathrm{~nm}$. As the share of silica in the system with lignin was four times higher, there was an increasing tendency to form particle aggregates. The SEM images (see Figure 3a,b) also showed that the kraft lignin/silica carrier was characterised by greater morphological diversity than kraft lignin on its own, because there were irregularly-shaped and porous microstructures observed in the aggregates of particles in the compound system. Rough, porous surfaces favour the immobilisation of microorganisms and their proliferation [37].

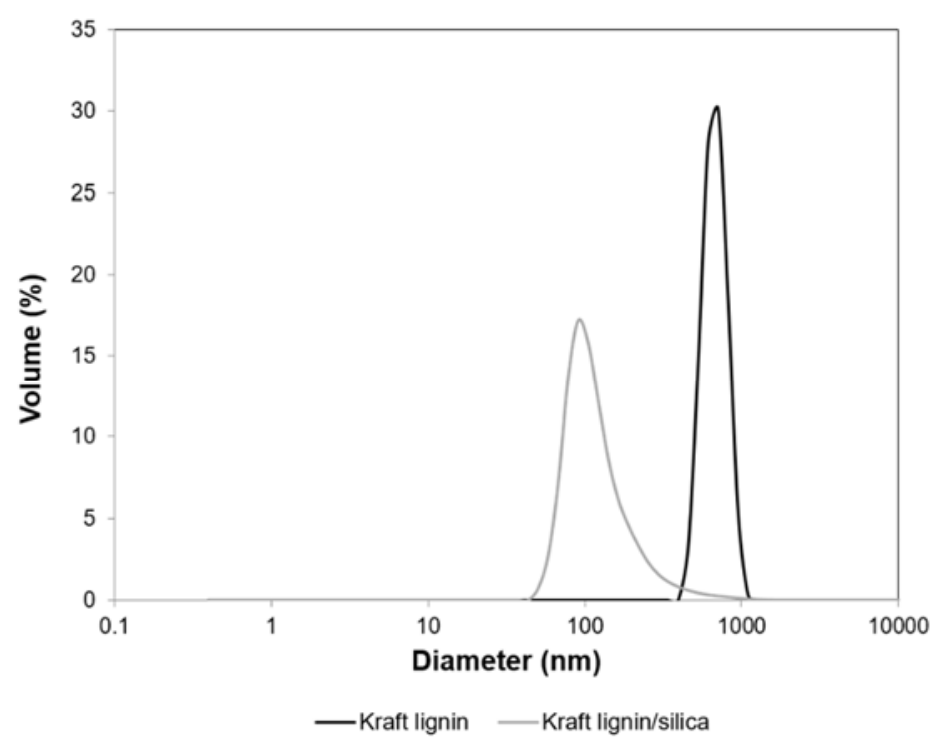

Figure 2. Particle size distributions by volume of kraft lignin and the kraft lignin/silica system.

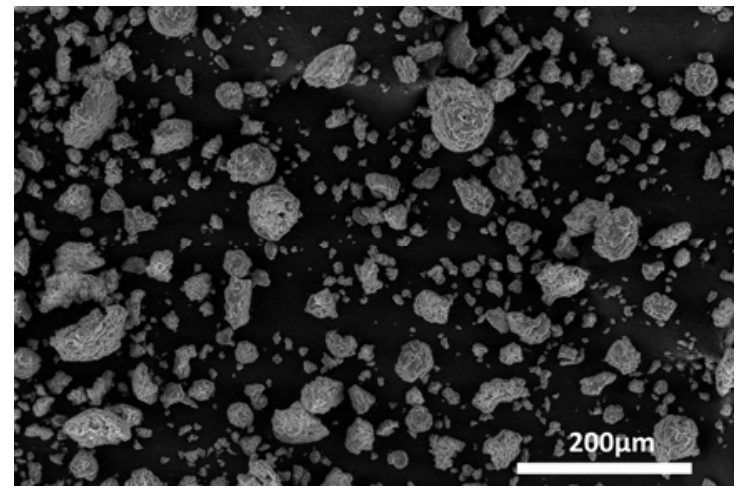

(a)

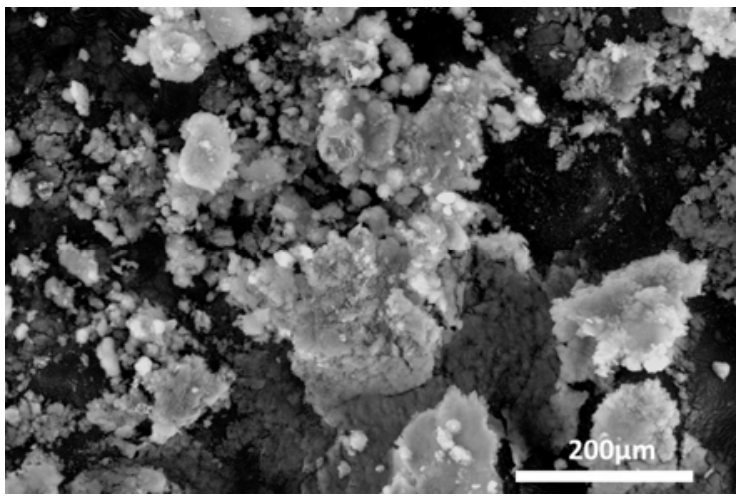

(b)

Figure 3. SEM images of kraft lignin (a) and the kraft lignin/silica system (b).

\subsubsection{Porous Structure Properties}

The formation of irregular particle clusters influences the degree of development of the BET specific surface [18]. As the results of the analyses in Table 2 indicate, the amount of silica in the 
system with lignin was four times greater and it significantly increased the $A_{\text {BET }}$ value. In spite of the considerable size of the pore diameters in pure lignin $(18.4 \mathrm{~nm})$, it was silica that developed the carrier surface up to $151.5 \mathrm{~m}^{2} \mathrm{~g}^{-1}$ and formed a porous microstructure with a pore volume of $0.35 \mathrm{~cm}^{3} \mathrm{~g}^{-1}$.

Table 2. Properties of the porous structure of kraft lignin [18] and the kraft lignin/silica system.

\begin{tabular}{|c|c|c|c|}
\hline Carriers & $\begin{array}{c}\mathrm{A}_{\mathrm{BET}} \\
\left(\mathrm{m}^{2} \mathrm{~g}^{-1}\right)\end{array}$ & $\begin{array}{c}V_{p} \\
\left(\mathrm{~cm}^{3} \mathrm{~g}^{-1}\right)\end{array}$ & $\begin{array}{c}\mathrm{S}_{\mathrm{p}} \\
(\mathrm{nm})\end{array}$ \\
\hline Kraft lignin & 1.9 & 0.01 & 18.4 \\
\hline Kraft lignin/silica & 151.5 & 0.35 & 10.8 \\
\hline
\end{tabular}

Figure 4 shows the nitrogen adsorption/desorption isotherms used in the work of the carrier materials. The nature of the isotherms points to their mesoporous structure. The $\mathrm{N}_{2}$ volume adsorbed by the kraft lignin/silica system was incomparably higher than that for pure lignin and amounted to about $225 \mathrm{~cm}^{3} \mathrm{~g}^{-1}$ STP, where the gas volume increased rapidly above the relative pressure value of 0.8 . The adsorption and desorption isotherms were used to determine the porous structure parameters in Table 2.

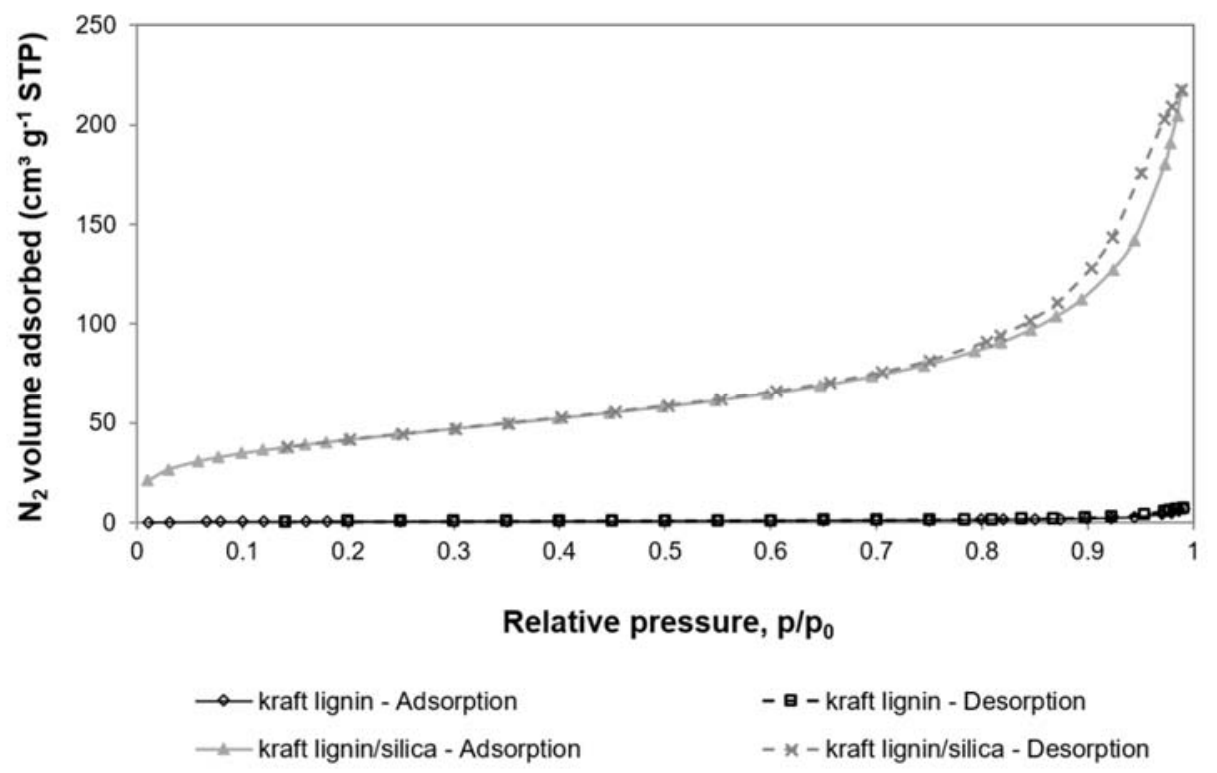

Figure 4. $\mathrm{N}_{2}$ adsorption/desorption isotherms of kraft lignin and the kraft lignin/silica system.

\subsubsection{FTIR Spectroscopy and Elemental Analysis}

According to the current state of knowledge in analytical chemistry and spectroscopy, lignin is an aromatic biopolymer (see Figure 5a) composed of three basic monomers in the form of p-coumaryl, coniferyl and sinapyl alcohols, differing in the degree of methoxylation [37]. Coniferyl alcohol, which has a methoxy group in position C3 in its structure, is the main lignin monomer in softwood. In hardwood, the structure of lignin is composed not only of coniferyl alcohol but also molecules of sinapine alcohol, which has -OCH3 groups substituted in positions $\mathrm{C} 3$ and $\mathrm{C} 5$. The third monomer, i.e., p-coumaryl alcohol, can be found in grasses [38]. The spectrum of pure lignin (Figure 6) includes bands assigned to the stretching vibrations $\mathrm{O}-\mathrm{H}\left(3600-3200 \mathrm{~cm}^{-1}\right)$, stretching vibrations $\mathrm{C}-\mathrm{H}$ (3004-2846 $\left.\mathrm{cm}^{-1}\right)$, vibrations of the ketone group $\mathrm{C}=\mathrm{O}\left(1710-1530 \mathrm{~cm}^{-1}\right)$ and the ones at 1599, 1512, 1426 , and $1368 \mathrm{~cm}^{-1}$ assigned to the stretching vibrations at the $\mathrm{C}-\mathrm{C}$ bonds in the aromatic skeleton. Subsequently, groups of bands can be observed at 1270,1218,1125, and $1033 \mathrm{~cm}^{-1}$, which correspond 
to the stretching vibrations of the bands $\mathrm{C}-\mathrm{O}$ and ether $\mathrm{C}-\mathrm{O}-\mathrm{C}$. The FTIR spectrum of lignin was described in detail by Pilarska et al. (2018) [18]. The high percentage of carbon in this compound is confirmed by the results of elemental analysis, shown in Table 3.

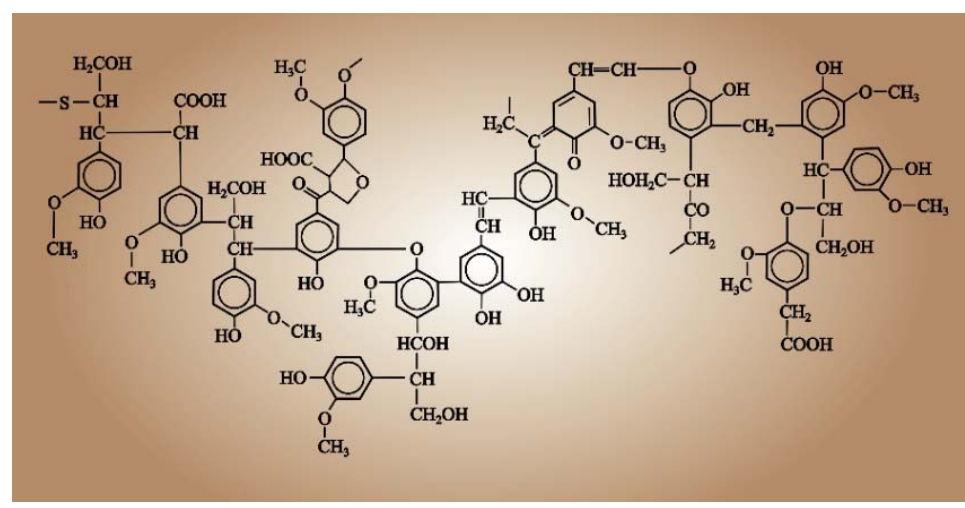

(a)

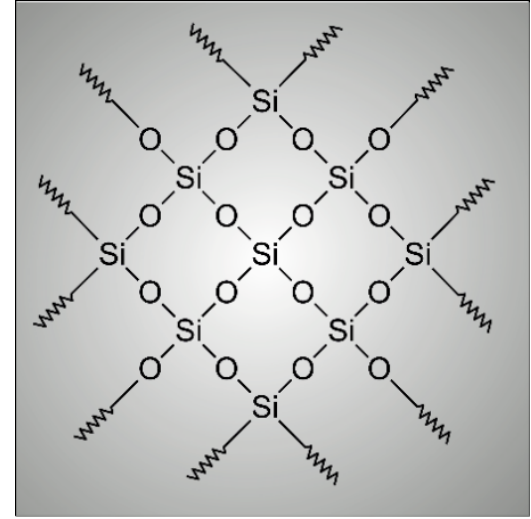

(b)

Figure 5. The structural formulas of (a) kraft lignin and (b) silica.

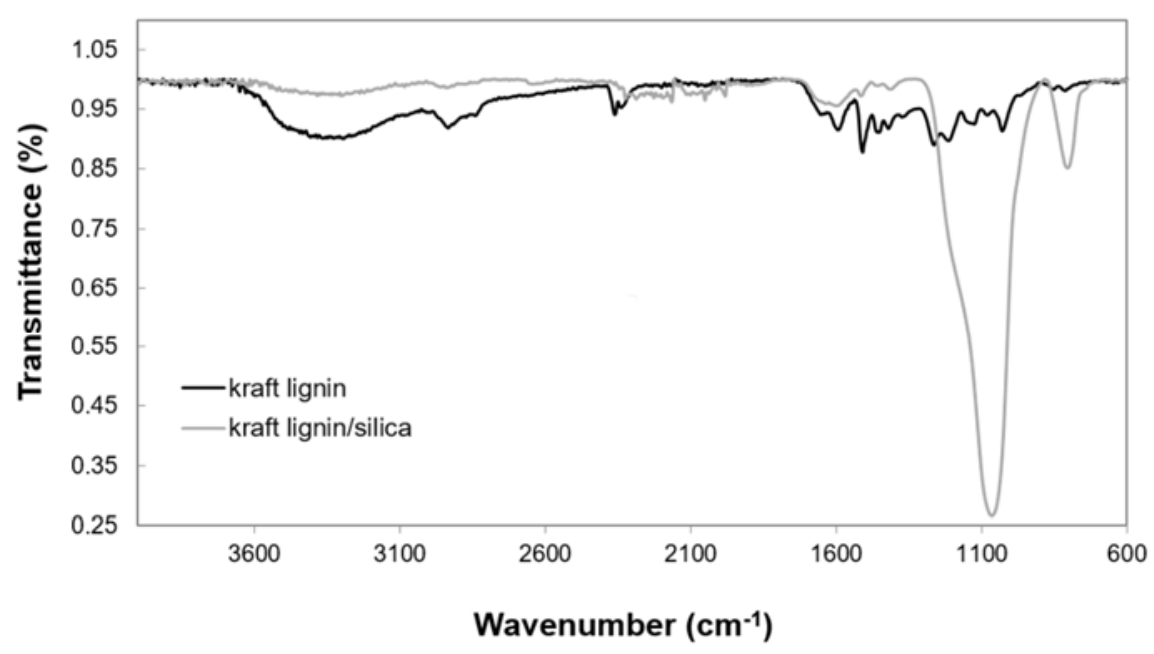

Figure 6. FTIR spectra of kraft lignin and the kraft lignin/silica system.

Table 3. The elemental content of kraft lignin [18] and the kraft lignin/silica system.

\begin{tabular}{ccccc}
\hline Carriers & $\begin{array}{c}\mathbf{C} \\
\mathbf{( \% )}\end{array}$ & $\begin{array}{c}\mathbf{H} \\
\mathbf{( \% )}\end{array}$ & $\begin{array}{c}\mathbf{S} \\
\left(\mathbf{\%}_{\text {TS }}\right)\end{array}$ & $\begin{array}{c}\mathbf{O} \\
\mathbf{( \% )}\end{array}$ \\
\hline Kraft lignin & 60.29 & 5.61 & 0.57 & - \\
Kraft lignin/silica & 4.03 & 0.4 & - & 3.41 \\
\hline
\end{tabular}

The surface of silicon dioxide is composed of silanol $(\equiv \mathrm{Si}-\mathrm{OH})$ and siloxane $(\equiv \mathrm{Si}-\mathrm{O}-\mathrm{Si} \equiv)$ groups-see Figure 5b. Silanol groups are reactive centres and indicate the hydrophilic nature of silica [39]. Thanks to silanol groups, the silica surface has an acidic nature due to the possibility of proton cleavage. On the other hand, the predominance of siloxane groups results in the hydrophobicity of the material. Thus, it is possible to say that silica has a hydrophilic or hydrophobic nature, depending on its surface structure. This is a key aspect in the modification of silica and its use as a cell carrier.

Nevertheless, it is important to note that the binding of lignin with silica in this experiment may have been considerably affected by the degree of methoxylation and by a significant number of hydroxyl and phenolic groups, which are characteristic of lignin isolated in the kraft process [38]. 
The FTIR spectrum of the kraft lignin/silica system (1:4 ratio by weight) differs significantly from the spectrum of pure lignin due to the dominant content of silica. Like the band of kraft lignin, the band of the kraft lignin/silica system ranges from 3600 to $3200 \mathrm{~cm}^{-1}$ and corresponds to $\mathrm{O}-\mathrm{H}$ stretching vibrations. On the other hand, the maximum at a wavenumber of approximately $1630 \mathrm{~cm}^{-1}$ is assigned to $\mathrm{O}-\mathrm{H}$ bending vibrations and corresponds to the presence of water bound physically to the material. The spectrum is dominated by the $1080 \mathrm{~cm}^{-1}$ band, which is assigned to $\mathrm{Si}-\mathrm{O}-\mathrm{Si}$ stretching vibrations, and by the $\sim 800 \mathrm{~cm}^{-1}$ band ( $\mathrm{Si}-\mathrm{O}$ stretching vibrations). The results of our experiment are consistent with the data published in earlier studies [40,41].

\subsubsection{Thermal Analysis}

The knowledge of the temperatures of decomposition of microbial carriers is particularly important for biotechnological processes conducted at increased temperature. During anaerobic digestion, the value of this parameter may be significant when the process is carried out under thermophilic conditions $\left(50-60^{\circ} \mathrm{C}\right)$. The thermal stability of kraft lignin and the kraft lignin/silica system (1:4 ratio by weight) was determined by means of thermogravimetric analysis (Figure 7).

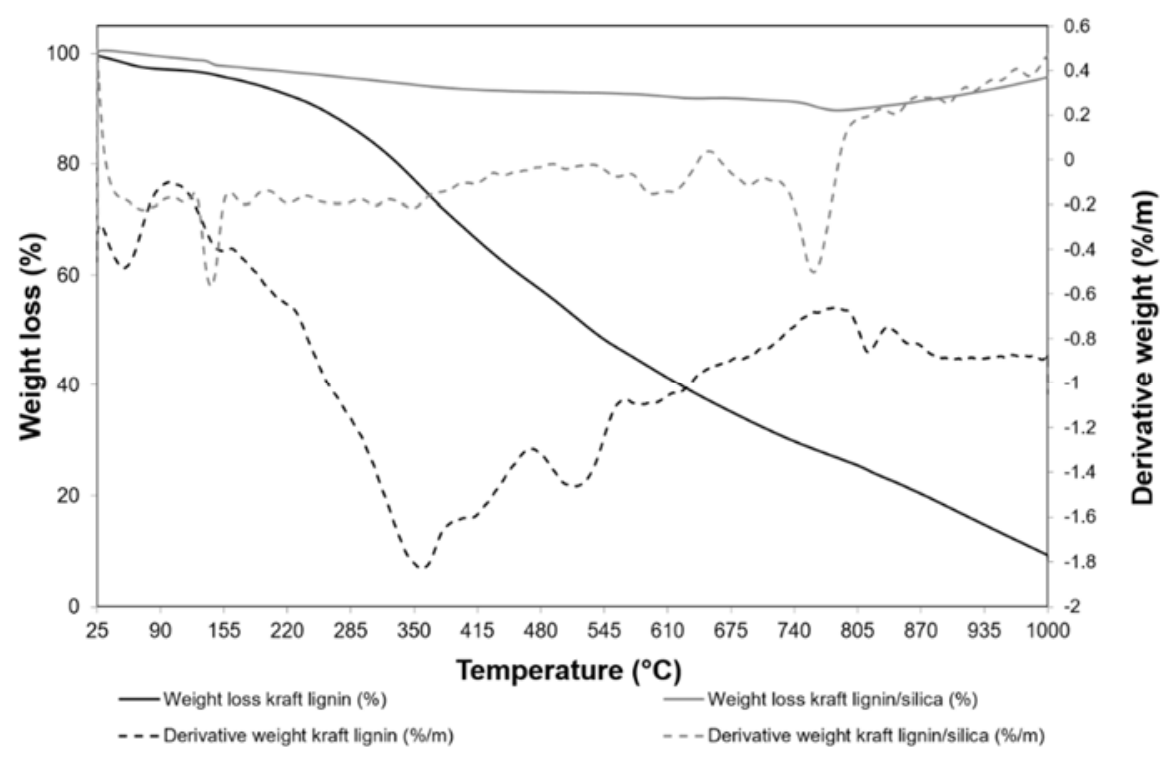

Figure 7. Thermograms of kraft lignin and the kraft lignin/silica system.

The thermal decomposition behaviour of pure kraft lignin was described in detail in an earlier study by Pilarska et al. (2018) [18]. According to the shape of the TG curve (solid black line), the pyrolysis of pure lignin can be described as a two-stage process, where the adsorbed/hydrated water is lost in the first phase, within a temperature range of $31-71^{\circ} \mathrm{C}$. Up to $215^{\circ} \mathrm{C}$, the weight loss was small and did not exceed $2.7 \%$. The main exothermic stage of lignin degradation took place within a temperature range of $250-570{ }^{\circ} \mathrm{C}$, when various volatile compounds, including phenolic compounds, as well as methanol and methane were released. The greatest weight loss (33.9\%) in the thermal decomposition of this compound occurred within a temperature range of $288-388^{\circ} \mathrm{C}$.

The kraft lignin/silica carrier, with the predominant content of silica, was much more thermally stable within a wide range of temperatures than pure lignin. As indicated by the shape of the TG curve (solid grey line), the highest weight loss at high temperatures $\left(\sim 745^{\circ} \mathrm{C}\right)$ amounted to $10 \%$. This result confirms one of numerous advantages of silica as an inorganic precursor and is consistent with the data provided in reference publications [42].

According to the latest scientific reports, the thermal stability of pure kraft lignin can be improved by phosphorylation with a green phosphating reagent, $\mathrm{NH}_{4} \mathrm{H}_{2} \mathrm{PO}_{4}$, in the presence of urea [11] . This procedure may extend its application as a flame-retardant material. Colloidal silicas exhibit high 
heat resistance and excellent mechanical properties. For this reason, they can be applied in light but strong composite materials made from carbon fibre, such as carbon-fibre-reinforced thermoplastics (CFRTPs) [43]. In this case, colloidal silica is adsorbed onto carbon fibres via electrodeposition, which enhances the interfacial properties of the CFRTP, and thus improves its thermal stability and mechanical properties.

To sum up, both pure kraft lignin and the kraft lignin/silica system, used as cell carriers in this study, are thermally stable within the temperatures of mesophilic and thermophilic digestion and can be used as cell carriers.

\subsection{Cell Growth and Cell Biomass}

The analysis of the results of colonisation of the kraft lignin and kraft lignin/silica system carriers by the autochthonous strain of Gram-positive, sporulating Bacillus amyloliquefaciens bacteria isolated from digested sewage sludge showed that the isolate strongly colonised the surface of both carriers (see Figure 8).

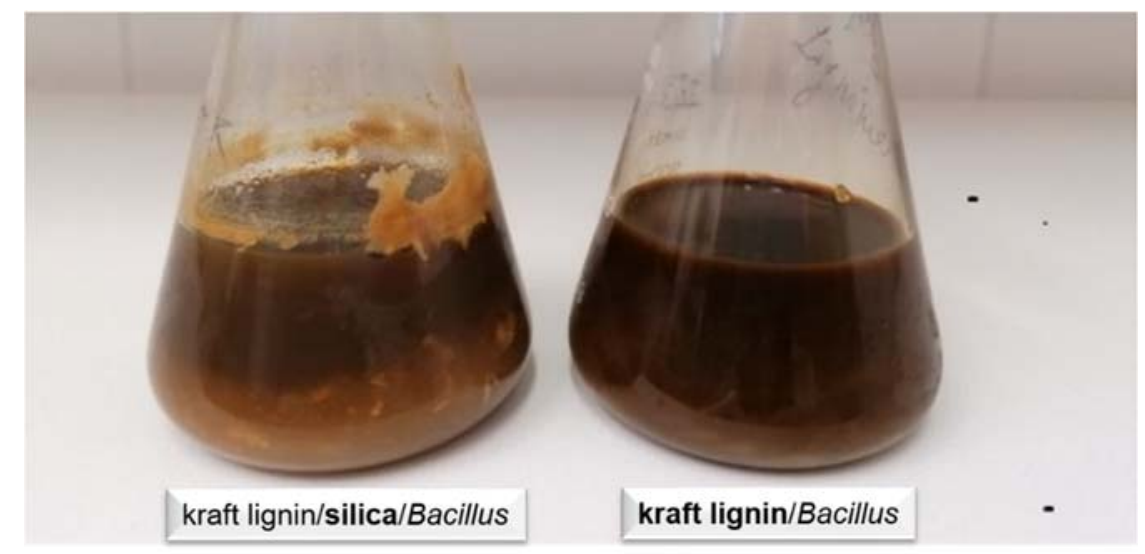

Figure 8. A Bacillus amyloliquefaciens cell culture with the carriers added.

The analysis of the results of colonisation of the kraft lignin and kraft lignin/silica system carriers by the autochthonous strain of Gram-positive, sporulating Bacillus amyloliquefaciens bacteria isolated from digested sewage sludge showed that the isolate strongly colonised the surface of both carriers (see Figure 8). The cell biomass calculated according to the authors' original procedure (Section 2.3) showed that the colonisation of the carrier with the predominant content of silica was much stronger. The cell biomass in the system with pure kraft lignin was $0.49 \pm 0.03 \mathrm{~g} / 100 \mathrm{~mL}$, whereas in the kraft lignin/silica system it was twice as high, i.e., $1.05 \pm 0.07 \mathrm{~g} / 100 \mathrm{~mL}$. The advantage of colonisation of the silica carrier can be easily noticed in the photo (Figure 8), and it was confirmed by SEM images (Figure 9a,b).

The increased proliferation of bacterial cells in the variant with the kraft lignin/silica system (1:4 by weight) was mainly caused by the considerable content of silica, which increased the microbial production of intracellular proteins, including enzymatic proteins [44]. Chen et al. (2020) researched anaerobic digestion of sewage sludge and observed that the addition of silica accelerated protein degradation in the sludge and simultaneously inhibited the degree of polysaccharide degradation. This increased the degradation of macromolecular organic components and resulted in higher methane production [28]. The production of biogas, including methane, may also increase due to the greater abundance and higher activity of methanogens. The dispersion and morphological properties of this compound, its porosity, well-developed specific BET surface and reactive centres on the surface provide favourable conditions for the adhesion and colonisation of bacterial cells. The Bacillus amyloliquefaciens bacteria have a well-developed enzyme apparatus, which enables them to decompose both easily-degradable and hard-to-degrade compounds [45,46]. Initial immobilisation 
of this bacterial strain with the carrier followed by the application of systems prepared in the hydrolysis phase of anaerobic digestion might increase the effectiveness of the AD process.

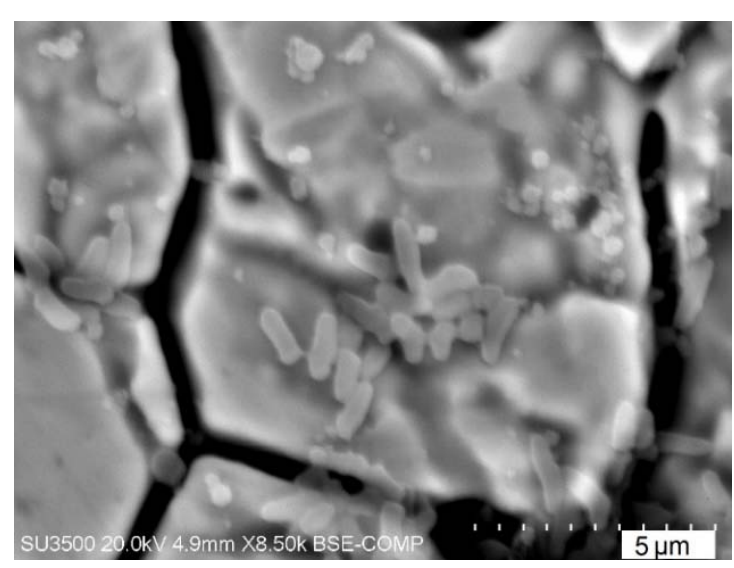

(a)

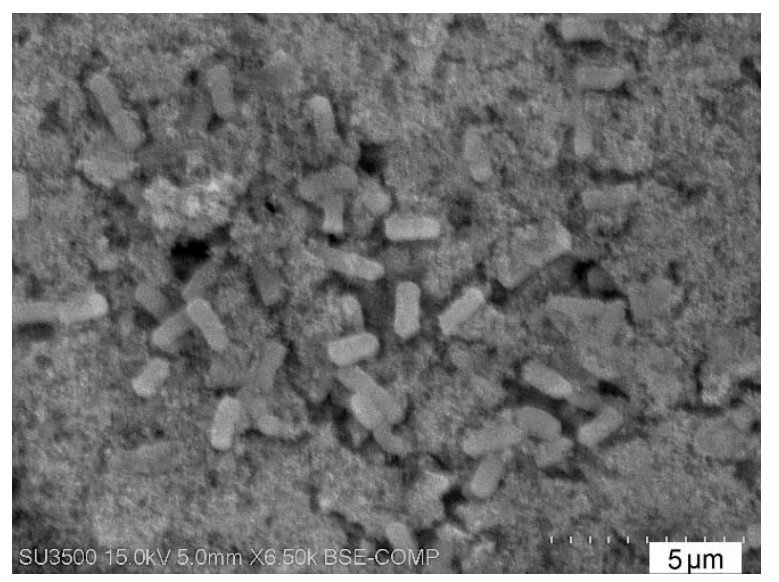

(b)

Figure 9. SEM images of Bacillus amyloliquefaciens colonisation of (a) kraft lignin and (b) the kraft lignin/silica system.

\subsection{Analysis of Digestate Samples}

\subsubsection{Total Bacterial Count}

The two-way analysis of variance showed that both the type of sample undergoing anaerobic digestion and the sampling term had highly significant influence on the growth and development of eubacteria and their enzymatic activity (see Table 4).

Table 4. F test statistics and significance levels of two-way analysis of variance for the cell count and activity of microorganisms; the combination and terms of tests were fixed factors $\left({ }^{* *} p=0001\right.$, ns-no significant difference).

\begin{tabular}{cccc}
\hline Parameter & Term & Combination & Interaction \\
\hline Bacteria & $168.77^{* * *}$ & $296.91^{* * *}$ & $32.59^{* * *}$ \\
Dehydrogenase & $133.57^{* * *}$ & $38.21^{* * *}$ & $1.01^{\mathrm{ns}}$ \\
\hline
\end{tabular}

The quantitative analysis of bacteria by means of fluorescence in situ hybridisation showed that during the continuous 14-day process of decomposition of each of the samples, the most intensive proliferation of microorganisms occurred in the SS + kraft lignin/silica variant (SS - sewage sludge; Figure 10). This also confirmed the result of the Bacillus amyloliquefaciens cell biomass obtained with this carrier (Figure 8).

The addition of pure lignin also increased the count of bacterial cells in the digested waste (see Figure 11). However, the microorganisms did not react as intensely as in the combination with silica. There was a statistically significant increase in bacterial proliferation in the SS + kraft lignin variant only at the fourth and fifth terms of the analyses. It is most likely that this effect was caused by the slow transformation of lignin methoxyl groups into active functional groups (mainly-COOH), which are an easily available source of carbon for microorganisms [47]. As shown in the results from reference publications, lignin has very good sorption properties, and also works as a carrier for immobilising bacteria and enzymes [48]. 


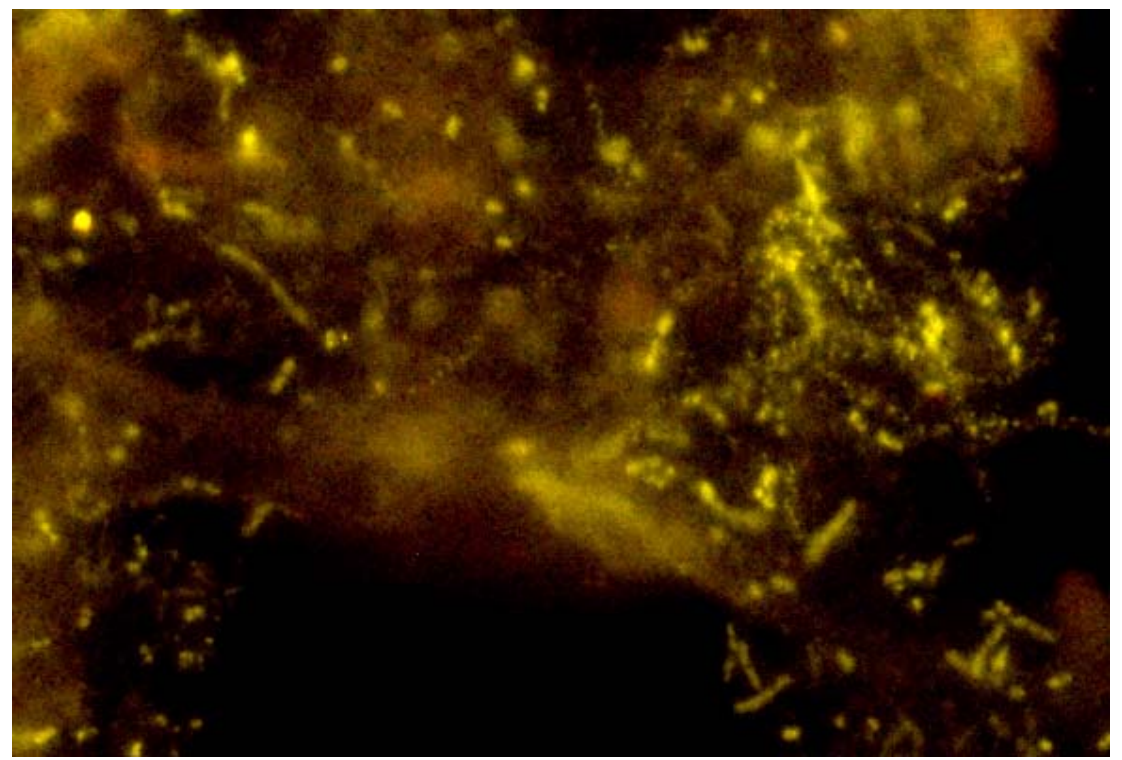

Figure 10. Specific identification of whole fixed bacterial cells with fluorescent oligonucleotide probes (FISH)—SS + kraft lignin/silica combination (400× magnification).

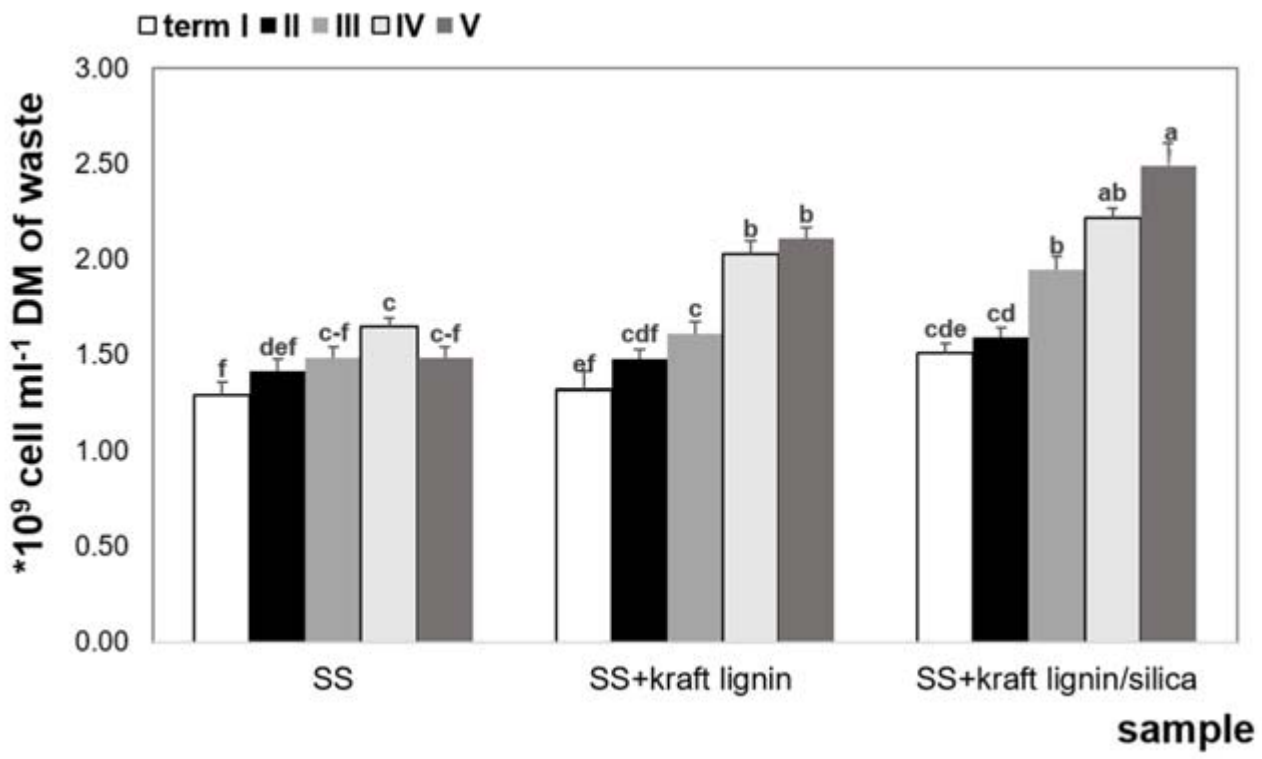

Figure 11. Changes in the total bacterial count in the digested samples. Explanation: a-f-different letters denote significant differences at $p=0.05$ (significance level). Means followed by the same letters do not differ significantly at $p=0.05$.

The term of the tests also had a statistically significant influence on the differences in the count of bacteria in the experimental objects under analysis, especially when silica and/or lignin were added. The proliferation of microorganisms in the sewage sludge digested with the cell carriers increased successively and reached the highest level at the last (fifth) term of analyses.

According to the current state of knowledge, the use of natural carriers extends the activity and stability of the consortium of microorganisms, and thus increases the efficiency of biotechnological processes, including anaerobic digestion. The carrier protects the cells of immobilised microorganisms if there are changes in the $\mathrm{pH}$ value, temperature, and composition of the medium [1,36]. 


\subsubsection{Dehydrogenase Activity}

The dynamics of changes in the dehydrogenase activity during the anaerobic digestion of sewage sludge had a different nature (Figure 12)—there was a successive decrease in the DHA in the experimental variants.

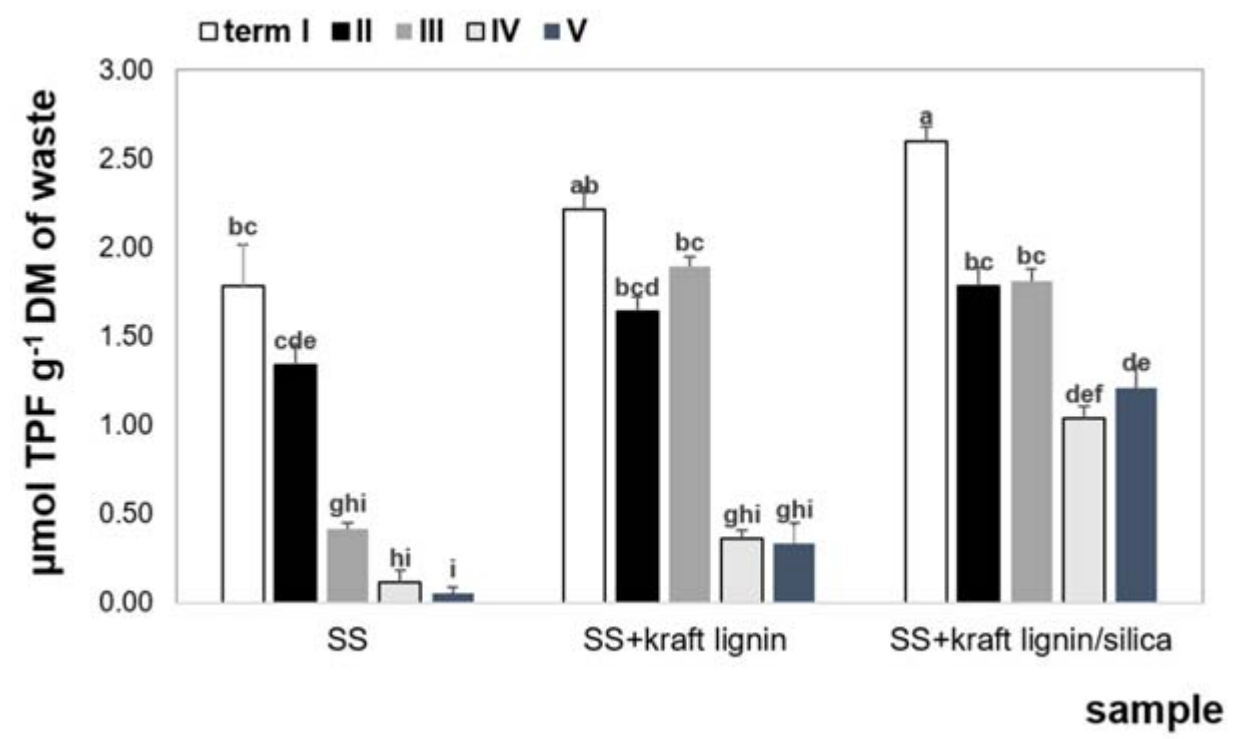

Figure 12. Changes in the dehydrogenase activity (DHA) in the digested samples. Explanation: $\mathrm{a}-\mathrm{i}-$ different letters denote significant differences at $p=0.05$ (significance level). Means followed by the same letters do not differ significantly at $p=0.05$.

Dehydrogenases are intracellular enzymes, which are regarded as biochemical indicators of the metabolic activity of microorganisms [49,50]. According to reference publications [51], the DHA is positively correlated with the content of organic matter in the substrate and the biomass of microorganisms. However, this correlation was not observed in our study. The statistical analysis showed a negative correlation between the count of bacteria and the activity of these enzymes in the experimental variants. The regression models (Equations (1)-(3)) clearly show that during the 14-day digestion process, the growing population of bacteria did not increase the dehydrogenase activity in digested waste. This may have been caused by specific inhibitors of microbial activity, such as sulphur, ammonia, heavy metals and antibiotics $[35,52]$.

$$
\begin{gathered}
\text { SS }=-15.019 x^{2}-49.5 x+40.83, R^{2}=0.84, p \leq 0.01 \\
\text { SS + lignin }=-2.2537 x^{2}+5.1259 x-0.7236, R^{2}=0.9626, p \leq 0.01 \\
\text { SS + lignin + silica }=-1.3662 x^{2}+3.3492 x+0.3384 R^{2}=0.9101, p \leq 0.01
\end{gathered}
$$

Similarly to the growth and development of bacteria, the highest dehydrogenase activity was noted in the variants with the carriers, especially with kraft lignin/silica.

\subsubsection{Zinc and Lead Concentration}

Among all heavy metals contained in sewage sludge, zinc is the one with the highest share. By contrast, lead is in the penultimate position in this ranking [35]. What distinguishes all heavy metals is the fact that, unlike many other toxic substances found in SS, they are not biodegradable and may accumulate at potentially toxic concentrations. Their toxic effect consists of disordering the functions and structure of enzymes by binding metals with thiol and other groups on protein molecules [53]. 
The suspension was collected in our experiment to verify the concentration of zinc and lead during the anaerobic digestion of each sample (Table 5). There were no breakpoints in the $\mathrm{Zn}$ and $\mathrm{Pb}$ concentrations, which inhibited the AD process [54].

Additionally, the collected suspension was separated into a liquid fraction (supernatant) and a solid fraction (sludge). There was a higher percentage of zinc in the solid fraction in the SS and SS + kraft lignin/silica samples than in the SS + kraft lignin sample, where the concentration of this metal in the centrifuged sludge was lower and may have resulted in better condition of the bacterial microflora. It is noteworthy that the principal component analysis showed clear positive relations between the bacterial biomass and the Zn content in the SS and SS + kraft lignin/silica objects (Section 3.5.2). However, the concentration of lead in both fractions, in all the samples, remained at the same level.

Table 5. Zinc and lead concentration in digested SS, SS + kraft lignin and SS + kraft lignin/silica samples.

\begin{tabular}{|c|c|c|c|c|c|c|c|}
\hline \multirow{2}{*}{\multicolumn{2}{|c|}{ Fractions Separation (\%) }} & \multicolumn{6}{|c|}{ Concentrations Balance (mg kg-1) } \\
\hline & & \multicolumn{3}{|c|}{$\mathrm{Zn}$} & \multicolumn{3}{|c|}{$\mathbf{P b}$} \\
\hline Supernat. & Sludge & Supernat. & Sludge & Total & Supernat. & Sludge & Total \\
\hline \multicolumn{8}{|c|}{ SS Sample } \\
\hline 63 & 37 & 0.31 & 41.10 & 41.42 & 0.013 & 2.765 & 2.778 \\
\hline 63 & 37 & 0.28 & 41.04 & 41.32 & 0.017 & 2.754 & 2.771 \\
\hline 65 & 35 & 0.36 & 42.22 & 42.58 & 0.022 & 2.731 & 2.753 \\
\hline \multicolumn{8}{|c|}{ SS + Kraft Lignin Sample } \\
\hline 45 & 55 & 1.50 & 46.48 & 47.97 & 0.020 & 2.725 & 2.745 \\
\hline 45 & 55 & 2.13 & 48.18 & 50.31 & 0.024 & 2.647 & 2.887 \\
\hline 46 & 54 & 2.24 & 47.92 & 50.16 & 0.028 & 2.708 & 2.736 \\
\hline \multicolumn{8}{|c|}{ SS + Kraft Lignin/Silica Sample } \\
\hline 52 & 48 & 0.45 & 44.29 & 44.74 & 0.010 & 1.781 & 1.792 \\
\hline 52 & 48 & 1.26 & 46.17 & 47.43 & 0.031 & 1.761 & 1.793 \\
\hline 58 & 42 & 1.23 & 45.76 & 46.99 & 0.029 & 1.414 & 1.444 \\
\hline
\end{tabular}

supernat—supernatant; $\mathrm{Zn}$-zinc; $\mathrm{Pb}$-lead.

\subsection{Continuous Mesophilic Anaerobic Digestion}

\subsubsection{Monitoring Process Stability}

During the three stages of the experiment, the following determinants of the process stability were measured: the VFA/TA ratio (volatile fatty acids-to-total alkalinity ratio), $\mathrm{pH}$ and the $\mathrm{N}-\mathrm{NH}_{4}{ }^{+}$ concentration. If specific values of these parameters are exceeded in anaerobic digestion, the process is inhibited and there is lower efficiency of methane production [55]. Different groups of bacteria take part in the AD process. They are characterised by different sensitivities to environmental changes. Archaea, the acetogenic and methanogenic bacteria, have stringent requirements and do not easily adapt to changing environmental conditions. If the $\mathrm{pH}$ of the system drops below 6.5 due to the accumulation of volatile fatty acids, bacterial cells proliferate much more slowly. By contrast, if temperature and $\mathrm{pH}$ are too high (above 7.2), $\mathrm{NH}_{3}(\mathrm{aq})$ is released. It can penetrate through the membranes of microorganisms, affect their cell osmoregulation and thus inhibit their activity [31]. For this reason, both propionic acid $(\mathrm{pH}<7)$ and ammonia $(\mathrm{pH}>7)$ are listed as the most common inhibitors of anaerobic digestion [54]. The monitoring of the process stability should also include measurements of VFA and/or total alkalinity (TA). As there are divergent reports on total alkalinity determining the conditions of process stabilisation [55], many researchers decided that it was best to assess the course of the AD process by measuring the VFA/TA ratio. According to the literature data, different ranges of the VFA/TA ratio are interpreted as follows: VFA/TA $\leq 0.40$ —stable digester, $0.40<$ VFA/TA $<0.80$ —some 
signs of instability, and VFA/TA $\geq 0.80$-significant stability [54]. Figures 13 and 14 show the dynamics of changes in these parameters.

The course of the anaerobic decomposition of pure SS was stable. The VFA/TA ratio was low-from 0.19 to 0.26 , whereas the $\mathrm{pH}$ value ranged from 6.88 to 7.32 . There were similar values of these parameters measured during the digestion of SS with the kraft lignin/silica system. The VFA/TA ratio was much lower than 0.4 , i.e., $0.24-0.26$, whereas the $\mathrm{pH}$ values ranged from 7.3 to 7.54 . There was higher $\mathrm{pH}$ at the beginning of the third stage of decomposition of the SS + kraft lignin/silica system, but it tended to decrease as the process progressed. At the second stage of the process, during the decomposition of the SS + kraft lignin sample, the $\mathrm{pH}$ value increased to 7.58 in the middle of the stage and then it tended to decrease, whereas the VFA/TA ratio increased to a maximum value of 0.45 . These values indicate certain destabilisation of the process, which may have affected the activity of methanogens. It is noteworthy that an increased alkaline $\mathrm{pH}$ influences the $\mathrm{NH}_{3}$ and $\mathrm{NH}_{4}{ }^{+}$dissociation equilibrium. The shape of the curves illustrating changes in the $\mathrm{N}-\mathrm{NH}_{4}{ }^{+}$concentration (Figure 14) points to values tolerated by methanogens in the SS variant $\left(1156-1277 \mathrm{mg} \mathrm{L}^{-1}\right)$ as well as in the SS + kraft lignin/silica system (1036-1265 $\left.\mathrm{mg} \mathrm{L}^{-1}\right)$ and slightly increased levels in the SS + kraft lignin combination (1322-1494 $\mathrm{mg} \mathrm{L}^{-1}$ ), but still referred to as non-inhibiting values [54]. On the other hand, it is most likely that the increased value of the VFA/TA ratio in the same sample (SS + kraft lignin) during partial degradation of lignin was caused by the release of furfural (an indirect product of the decomposition of carbohydrates, including cellulose) and derivatives of phenolic alcohols [56,57]. During the second stage, the biogas/methane production was transiently inhibited, which may have affected the final result (Figure 15).

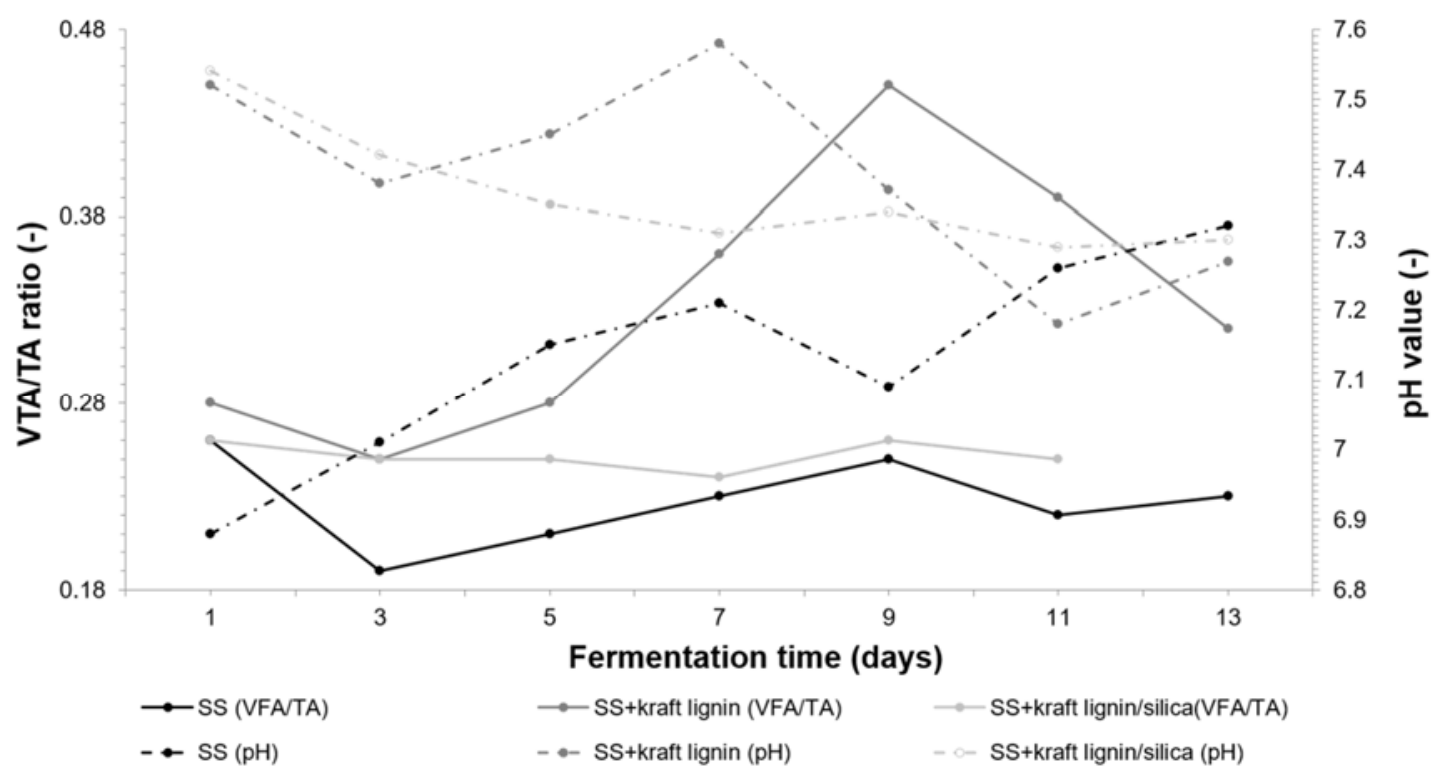

Figure 13. Changes in $\mathrm{pH}$ and the VFA/TA ratio during the anaerobic digestion of the SS, SS + kraft lignin and SS + kraft lignin/silica samples. 


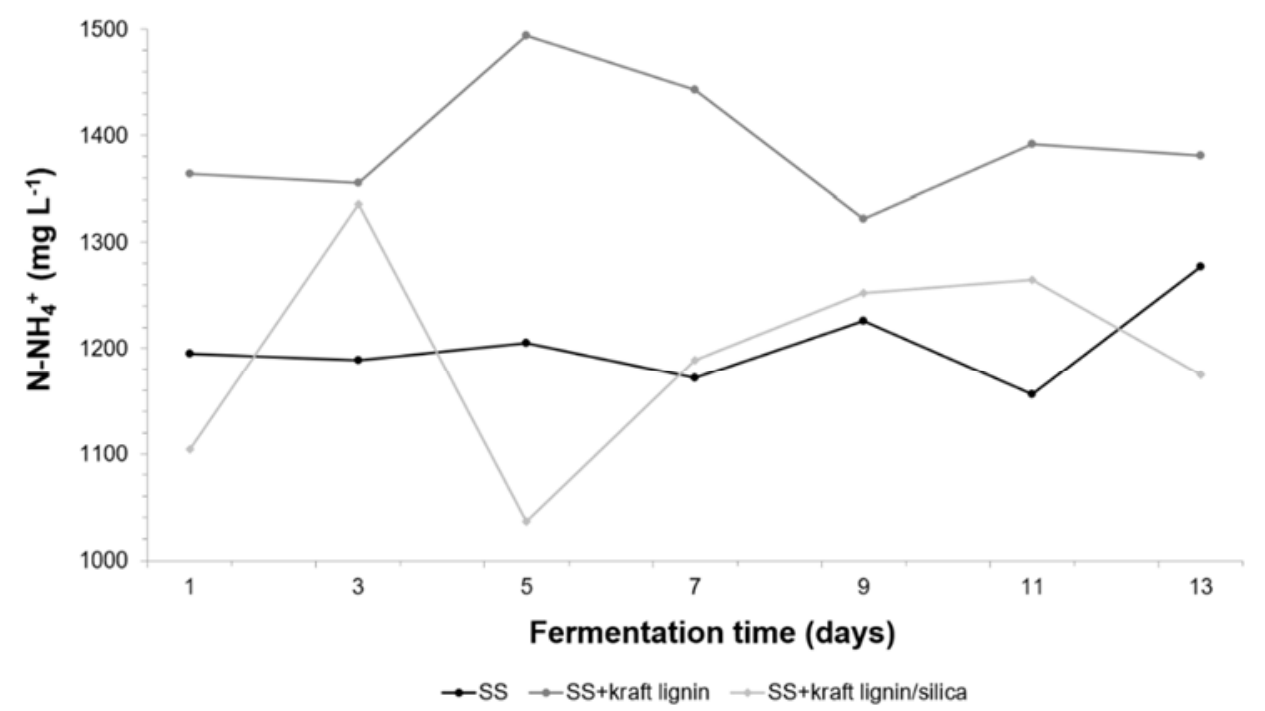

Figure 14. Changes in the $\mathrm{N}-\mathrm{NH}_{4}{ }^{+}$level during the anaerobic digestion of the SS, SS $+\mathrm{kraft}$ lignin and SS + kraft lignin/silica samples.

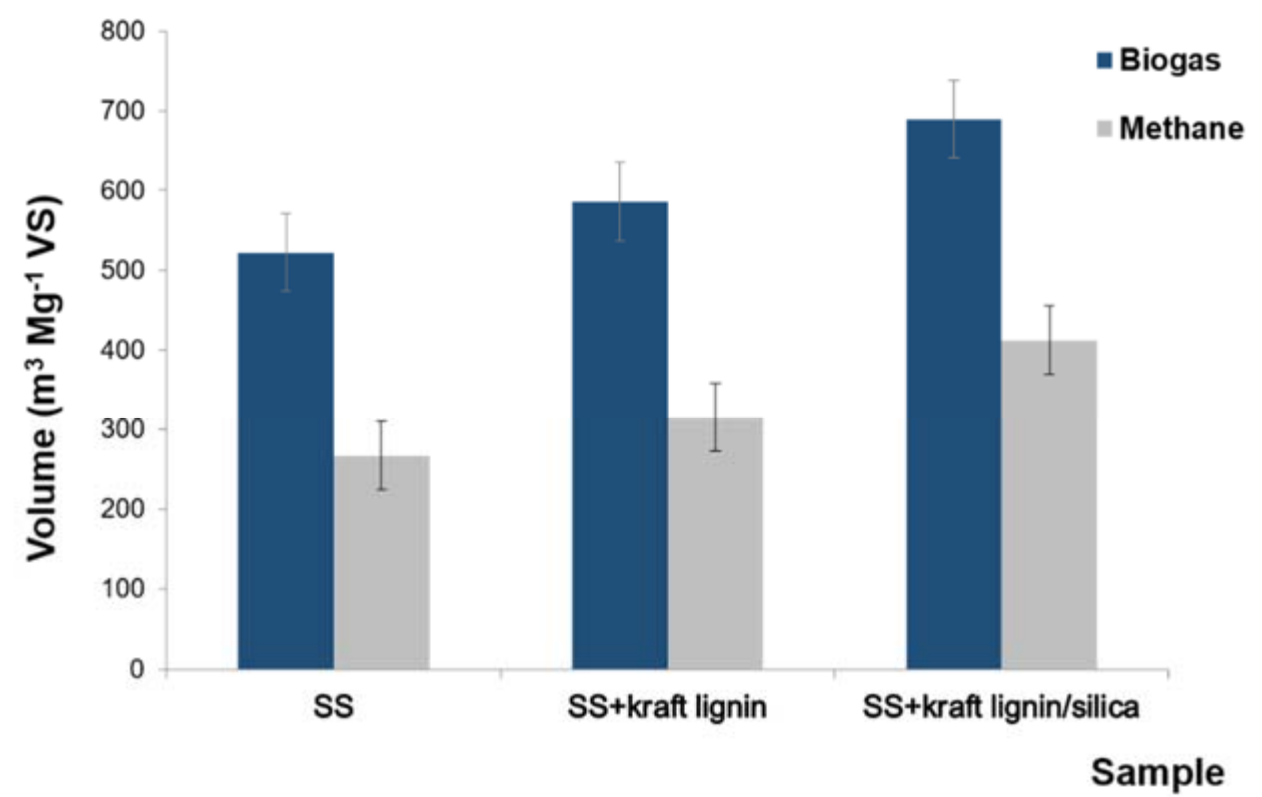

Figure 15. The efficiency of biogas and methane production per $\mathrm{Mg}$ of volatile solids obtained from SS, SS + kraft lignin and SS + kraft lignin/silica samples.

\subsubsection{Process Efficiency}

The three-stage experiment on the continuous anaerobic digestion of successive samples based on sewage sludge resulted in the following average production efficiencies: SS- $526 \mathrm{~m}^{3} \mathrm{Mg}^{-1}$ VS biogas, including $267 \mathrm{~m}^{3} \mathrm{Mg}^{-1}$ VS methane (51\%), SS + kraft lignin-586 $\mathrm{m}^{3} \mathrm{Mg}^{-1}$ VS biogas, including $316 \mathrm{~m}^{3} \mathrm{Mg}^{-1}$ VS methane (54\%), SS + kraft lignin/silica-689 $\mathrm{m}^{3} \mathrm{Mg}^{-1}$ VS biogas, including $413 \mathrm{~m}^{3} \mathrm{Mg}^{-1} \mathrm{VS}$ methane (60\%) (see Figure 15).

The value of biogas efficiency for SS in this study was greater [58] or comparable [17] to the results noted in earlier studies conducted by the author. The methane content in biogas was identical [17]. This result is similar to the data provided in available reference publications [59]. It is noteworthy that there may be considerable differences in the efficiency of biogas/methane production from sewage sludge coming from the same sewage treatment plant (and even bigger differences if sewage sludge 
comes from different sources). These differences observed in subsequent experiments may be caused by changes in the composition of sewage, including differences in the content of compounds inhibiting the process (heavy metals and toxic substances) [60]. The results may also be significantly influenced by the operating mode, configurations and sizes of bioreactors, applied technologies/process parameters, and organic loading rate (OLR).

However, as far as the effectiveness of the additives used in the experiment is concerned, the yield of biogas resulting from the continuous mode of anaerobic digestion with pure kraft lignin was lower than that the biogas yield noted in our previous study [17], i.e., $746.82 \mathrm{~m}^{3} \mathrm{Mg}^{-1} \mathrm{VS}$. The volume of methane was comparable, but the volume of biogas obtained in this study (586 $\left.\mathrm{m}^{3} \mathrm{Mg}^{-1} \mathrm{VS}\right)$ was lower. The result may have been influenced by both the composition of sewage sludge and the continuous operation mode of the bioreactor, during which the production of biogas was temporarily inhibited-most likely by an excessive load of organic substance. This situation did not occur during the anaerobic digestion of the third sample of sewage sludge with the kraft lignin/silica system (1:4 by weight), where the highest efficiency was noted. Due to the addition of silica, this system was also characterised by the highest proliferation of bacteria (Figure 11), as shown by measurement of the Bacillus amyloliquefaciens cell biomass (Figure 8). Moreover, the principal component analysis (PCA) (Figure 16) confirmed the strongest relationship between the size of bacterial biomass and methane emission $(R=0.8783)$ in this variant $(\mathrm{SS}+\mathrm{kraft}$ lignin/silica). This material is an excellent cell carrier in anaerobic digestion due to the functional properties of both substances forming the kraft lignin/silica hybrid, i.e., lignin sorption and the microstructural properties of silica. Silica nanoparticles have the potential to be used in nanomedicine as drug carriers, cell markers, imaging agents, biosensors, etc. This compound not only adsorbs proteins (the concept of differential protein adsorption), but also stimulates their multiplication [21]. The high potential of an advanced functional silica/lignin material for use in science and industry (e.g., as an adsorbent for heavy metals) was noted by Klapiszewski et al. (2013, 2015, 2015a), who presented various methods of its production and modification and analysed its properties in detail $[40,41,61]$. Given the high efficiency of the kraft lignin/silica carrier in the anaerobic digestion process, it may be highly competitive to other support materials [62], including carbon-based materials [63] and charcoal [64]. Carbon-based materials have been proven to reduce operational instability and substrate-induced inhibition, which hinder the microbial organic matter breakdown activity [63]. By contrast, according to publications, the use of cedar charcoal as a support material for microbial attachment could enhance methane production during the anaerobic digestion of crude glycerol and wastewater sludge. The methane yield from a charcoal-containing reactor was approximately 1.6 times higher than the yield from a reactor without charcoal [63]. This result is highly comparable to the yield of methane from the SS and SS + kraft lignin/silica samples. However, the use of the kraft lignin/silica hybrid may be much more advantageous than the application of the carrier materials described in reference publications for economic reasons and due to problems in maintaining the stability of the digestion process [62-64]. It is also important that neither lignin nor silica need to be separated from the digested pulp, even if the digestate is to be used as a fertiliser. The costs of isolation of the carrier material would certainly be higher than the profit from recycling. Another advantage is small amounts of the substance recommended in the study to be used as a microbial carrier. Apart from that, both lignin and silica are environmentally friendly. As was mentioned in the Introduction, lignin positively affects the formation of soil organic matter, its structure and bioactivity. It also acts as a chelating agent, which reduces the leaching of iron and zinc [65]. At the same time, lignin is a urease inhibitor, which can reduce the nitrification of urea and help to retain it in the soil [16].

Principal component analysis (PCA) was applied to demonstrate the cause-and-effect relationships between the following parameters: cell biomass, dehydrogenase activity, $\mathrm{CH}_{4}$ emission, $\mathrm{N}_{-} \mathrm{NH}_{4}{ }^{+}$, VFA/TA ratio, $\mathrm{Zn}, \mathrm{Pb}$ (see Figure 16). The PCA demonstrated the regularities between the independent variables. The components being a linear combination of the variables under consideration were determined. The PCA enabled the identification of the initial variables, 
which constituted a frame of reference for the other variables. It is noteworthy that a considerable amount of variation (over 70\%) was explained in the new coordinate system.

The PCA showed that the type of interaction between the parameters depended on the type of experimental variant. The samples digested with the cell carrier were characterised by a positive relationship between the cell biomass and methane emission. There was also a positive interaction between the bacterial content and the concentration of ammonium ions in the SS variant and the VFA/TA ratio in the SS + kraft lignin and SS + kraft lignin/silica combinations. The addition of silica was also marked by the occurrence of a negative correlation between the $\mathrm{pH}$ of digested sludge and the emission of methane and the content of ammonium ions.

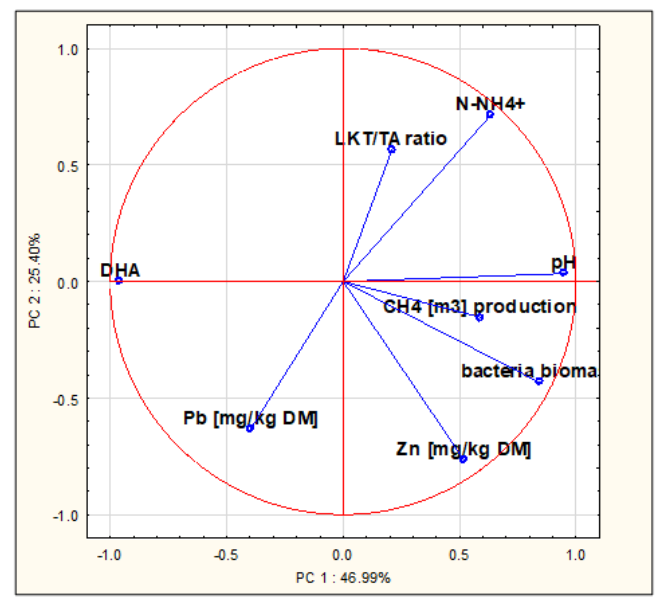

(a)

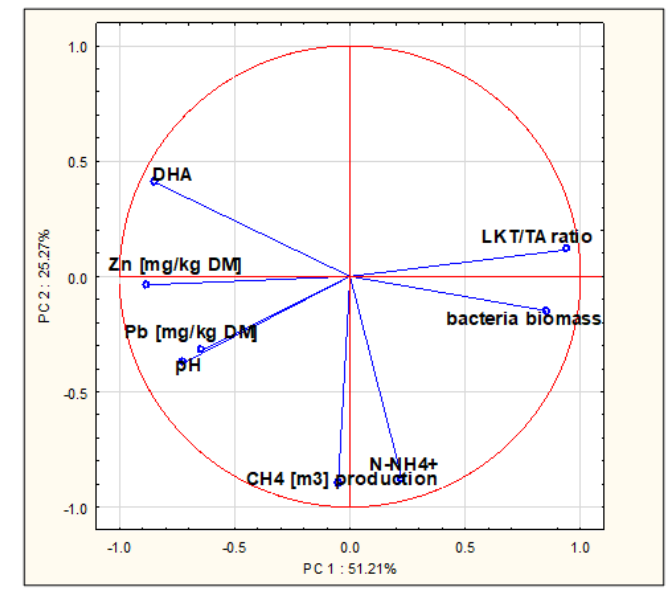

(b)

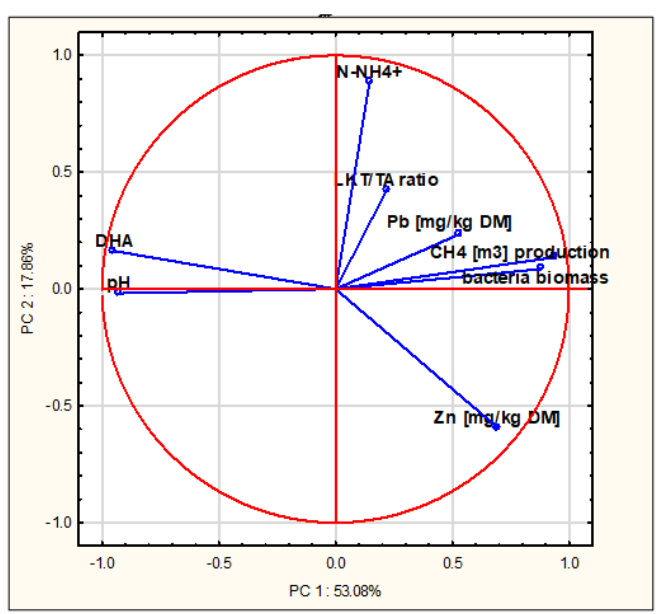

(c)

Figure 16. The distribution of bacterial biomass, activity and the chemical properties in the anaerobic digestion in two PCA axes. Legend: (a)—SS sample, (b)—SS + kraft lignin sample, (c) —SS + kraft lignin/silica sample; DHA—dehydrogenase activity, VFA/TA ratio-volatile fatty acids-to-total alkalinity ratio, $\mathrm{CH}_{4}$ - methane emission, $\mathrm{N}_{-} \mathrm{NH}_{4}{ }^{+}$- ammonium nitrate, $\mathrm{Zn}$-zinc, $\mathrm{Pb}$-lead.

\section{Conclusions}

The results of the experiment lead to the following conclusions:

1. The kraft lignin/silica material (1:4 by weight) was characterised by better properties than pure kraft lignin as a cell carrier: very well-developed BET specific surface, high pore volume, high thermal stability. 
2. The proliferation of Bacillus amyloliquefaciens bacterial cells was more intensive in the kraft lignin/silica system, where the cellular biomass was twice as large as in the culture with pure kraft lignin.

3. The quantitative analysis conducted by means of in situ fluorescence showed increased proliferation of microorganisms during the anaerobic digestion in the SS + kraft lignin/silica variant. The addition of pure kraft lignin also increased cell proliferation, but to a lesser extent.

4. The highest dehydrogenase activity was observed during the decomposition of the sample with silica. In the course of the process, the value of this parameter tended to decrease in each experimental variant.

5. As indicated by the values of monitoring parameters, the course of the AD process was stable in the SS and SS + kraft lignin/silica samples. There was a temporary increase in the VFA/TA ratio accompanied by simultaneous inhibition of biogas/methane production in the SS + kraft lignin sample. It is most likely that this effect was caused by the release of lignin decomposition products, i.e., furfural and/or derivatives of phenolic alcohols.

6. During the continuous anaerobic decomposition of three samples based on sewage sludge, the largest amount of biogas was produced from the SS + kraft lignin/silica system $\left(689 \mathrm{~m}^{3} \mathrm{Mg}^{-1} \mathrm{VS}\right.$, including $413 \mathrm{~m}^{3} \mathrm{Mg}^{-1}$ VS methane). There were comparable amounts of biogas produced from the SS sample (526 $\mathrm{m}^{3} \mathrm{Mg}^{-1}$ VS biogas, including 51\% methane) and the SS + kraft lignin sample (586 $\mathrm{m}^{3} \mathrm{Mg}^{-1}$ VS biogas, including $54 \%$ methane).

The functional properties of the compounds forming the kraft lignin/silica hybrid, e.g., the lignin sorption and silica microstructure, mean that this material can be successfully used as a cell carrier and cell development activator in the anaerobic digestion process.

Author Contributions: Conceptualization, A.A.P.; methodology, A.A.P. and A.W.-M.; software, K.P.; validation, A.A.P. and A.W.-M.; formal analysis, A.A.P.; investigation, A.A.P, A.W.-M., K.P., A.N., A.O.; resources, A.A.P., A.W.-M., A.N.; data curation, A.A.P., A.W.-M. and A.O.; writing-original draft preparation, A.A.P.; writing-review and editing, A.A.P., A.W.-M.; visualization, K.P. and A.O.; supervision, K.P.; project administration, A.A.P.; funding acquisition, A.A.P. and A.N. All authors have read and agreed to the published version of the manuscript.

Funding: This research was funded by the National Science Centre, Poland (grant no. DEC-2019/03/ST8/01867).

Conflicts of Interest: The authors declare no conflict of interest.

\section{References}

1. Dzionek, A.; Wojcieszyńska, D.; Guzik, U. Natural carriers in bioremediation: A review. Electron. J. Biotechnol. 2016, 23, 28-36.

2. Weiß, S.; Zankel, A.; Lebuhn, M.; Petrak, S.; Somitsch, W.; Guebitz, G.M. Investigation of microorganisms colonising activated zeolites during anaerobic biogas production from grass silage. Bioresour. Technol. 2011, 102, 4353-4359. [PubMed]

3. Purnomo, C.W.; Mellyanawaty, M.; Budhijanto, W. Simulation and experimental study on iron impregnated microbial immobilization in zeolite for production of biogas. Waste Biomass Valor. 2017, 8, 2413-2421.

4. Ivanova, G.; Rákhely, G.; Kovács, K.L. Hydrogen production from biopolymers by Caldicellulosiruptor saccharolyticus and stabilization of the system by immobilization. Int. J. Hydrogen Energy 2008, 33, 6953-6961.

5. Gong, W.; Ran, Z.; Ye, F.; Zhao, G. Lignin from bamboo shoot shells as an activator and novel immobilizing support for $\alpha$-amylase. Food Chem. 2017, 228, 455-462. [PubMed]

6. Ge, Y.; Qin, L.; Li, Z. Lignin microspheres: An effective and recyclable natural polymer-based adsorbent for lead ion removal. Mater. Des. 2016, 95, 141-147.

7. Milczarek, G.; Inganas, O. Renewable cathode materials from biopolymer/conjugated polymer interpenetrating networks. Science 2012, 335, 1468-1471.

8. Gnedenkov, S.V.; Opra, D.P.; Sinebryukhov, S.L.; Tsvetnikov, A.K.; Ustinov, A.Y.; Sergienko, V.I. Hydrolysis lignin-based organic electrode material for primary lithium batteries. J. Solid State Electrochem. 2014, 17, 2611-2621. 
9. Mamilla, J.L.K.; Novak, U.; Grilc, M.; Likozar, B. Natural deep eutectic solvents (DES) for fractionation of waste lignocellulosic biomass and its cascade conversion to value-added bio-based chemicals. Biomass Bioenergy 2019, 120, 417-425.

10. Jasiukaitytè Grojzdek, E.; Huš, M.; Grilc, M.; Likozar, B. Acid catalysed $\alpha-O-4$ aryl-ether bond cleavage in methanol/(aqueous) ethanol: Understanding depolymerisation of a lignin model compound during organosolv pretreatment. Sci. Rep. 2020, 10, 11037. [PubMed]

11. Gao, C.; Zhou, L.; Yao, S.; Qin, C.; Fatehi, P. Phosphorylated kraft lignin with improved thermal stability. Int. J. Biol. Macromol. 2020, 162, 1642-1652.

12. Settera, C.; Costa, K.L.S.; de Oliveira, T.J.P.; Mendes, R.F. The effects of kraft lignin on the physicomechanical quality of briquettes produced with sugarcane bagasse and on the characteristics of the bio-oil obtained via slow pyrolysis. Fuel Process. Technol. 2020, 210, 106561.

13. Yan, Q.; Boardman, C.R.; Cai, Z. Thermal stability of metal-lignin composites prepared by coprecipitation method. Thermochim. Acta 2020, 690, 178659.

14. Bjelić, A.; Likozar, B.; Grilc, M. Scaling of lignin monomer hydrogenation, hydrodeoxygenation and hydrocracking reaction micro-kinetics over solid metal/acid catalysts to aromatic oligomers. Chem. Eng. J. 2020, 399, 125712.

15. Bartocci, P.; Tschentscher, R.; Stensrød, R.E.; Barbanera, M.; Fantozzi, F. Kinetic analysis of digestate slow pyrolysis with the application of the master-plots method and independent parallel reactions scheme. Molecules 2019, 24, 1657-1672.

16. Jiao, G.J.; Xu, Q.; Cao, S.L.; Peng, P.; She, D. Controlled-release fertilizer with lignin used to trap urea/hydroxymethylurea/urea-formaldehyde polymers. Bioresources 2018, 13, 1711-1728.

17. Pilarska, A.A.; Pilarski, K.; Wolna-Maruwka, A. Cell immobilization on lignin-polyvinylpyrrolidone material used for anaerobic digestion of waste wafers and sewage sludge. Environ. Eng. Sci. 2019, 36, 478-490.

18. Pilarska, A.A.; Wolna-Maruwka, A.; Pilarski, K. Kraft lignin grafted with polyvinylpyrrolidone as a novel microbial carrier in biogas production. Energies 2018, 11, 3246-3268.

19. Pilarska, A.A.; Wolna-Maruwka, A.; Pilarski, K.; Janczak, D.; Przybył, K.; Gawrysiak-Witulska, M. The use of lignin as a microbial carrier in the co-digestion of cheese and wafer waste. Polymers 2019, 11, 2073-2093.

20. Jesionowski, T. Characterisation of pigments obtained by adsorption of C.I. Basic Blue 9 and C.I. Acid Orange 52 dyes onto silica particles precipitated via the emulsion route. Dyes Pigment. 2005, 67, 81-92.

21. Jesionowski, T.; Nowacka, M.; Ciesielczyk, F. Electrokinetic properties of hybrid pigments obtained via adsorption of organic dyes on the silica support. Pigment Resin Technol. 2012, 41, 9-19.

22. Hayashi, J.; Shoji, T.; Watada, Y.; Muroyama, K. Preparation of silica-lignin xerogel. Langmuir 1997, 13, 4185-4186.

23. Štandeker, S.; Novak, Z.; Knez, Ž. Adsorption of toxic organic compounds from water with hydrophobic silica aerogels. J. Colloidal Interface Sci. 2007, 310, 362-368.

24. Aguado, J.; Arsuaga, J.M.; Arencibia, A.; Lindo, M.; Gascón, V. Aqueous heavy metals removal by adsorption on amine-functionalized mesoporous silica. J. Hazard. Mater. 2009, 163, 213-221. [PubMed]

25. Saikia, J.; Yazdimamaghani, M.; Moghaddam, S.P.H.; Ghandehari, H. Differential protein adsorption and cellular uptake of silica nanoparticles based on size and porosity. ACS Appl. Mater. Interfaces 2016, 8, 34820-34832. [PubMed]

26. Clemments, A.M.; Botella, P.; Landry, C.C. Protein adsorption from biofluids on silica nanoparticles: Corona analysis as a function of particle diameter and porosity. ACS Appl. Mater. Interfaces 2015, 7, 21682-21689.

27. Dai, X.; Xu, Y.; Dong, B. Effect of the micron-sized silica particles (MSSP) on biogas conversion of sewage sludge. Water Res. 2017, 115, 220-228.

28. Chen, S.; Dong, B.; Yang, D.; Li, N.; Dai, X. Micron-sized silica particles in wastewater influenced the distribution of organic matters in sludge and their anaerobic degradation. J. Hazard. Mater. 2020, 393, 122340.

29. Chauhan, A.; Ogram, A. Evaluation of support matrices for immobilization of anaerobic consortia for efficient carbon cycling in waste regeneration. Biochem. Biophys. Res. Commun. 2005, 327, 884-893.

30. German Institute for Standardization. Characterisation of the Substrate, Sampling, Collection of Material Data, Fermentation Tests; Norm DIN 38 414-S8; German Institute for Standardization: Berlin, Germany, 1985.

31. Pilarska, A.A.; Pilarski, K.; Wolna-Maruwka, A.; Boniecki, P.; Zaborowicz, M. Use of confectionery waste in biogas production by the anaerobic digestion process. Molecules 2019, 24, 37-50. 
32. Amann, R.I.; Krumholz, L.; Stahl, D.A. Fluorescent-oligonucleotide probing of whole cells for determinative, phylogenetic, and environmental studies in microbiology. J. Bacteriol. 1990, 172, 762-770.

33. Amann, R.I.; Binder, B.J.; Olson, R.J.; Chisholm, S.W.; Devereux, R.; Stahl, D.A. Combination of 16SrRNAtargeted oligonucleotide probes with flow cytometry for analyzing mixed microbial populations. Appl. Environ. Microbiol. 1990, 56, 1919-1925.

34. Camiña, F.; Trasar-Cepeda, C.; Gil-Sotres, F.; Leirós, C. Measurement of dehydrogenase activity in acid soilsrich in organic matter. Soil Biol. Biochem. 1998, 30, 1005-1011.

35. Pilarska, A.A.; Pilarski, K.; Waliszewska, B.; Zborowska, M.; Witaszek, K.; Waliszewska, H.; Kolasiński, M.; Szwarc-Rzepka, K. Evaluation of bio-methane yields for high-energy organic waste and sewage sludge: A pilot-scale study for a wastewater treatment plant. Environ. Eng. Manag. J. 2019, 18, 2019-2030.

36. Pilarska, A.A.; Pilarski, K.; Witaszek, K.; Waliszewska, H.; Zborowska, M.; Waliszewska, B.; Kolasiński, M.; Szwarc-Rzepka, K. Treatment of dairy waste by anaerobic digestion with sewage sludge. Ecol. Chem. Eng. S 2016, 23, 99-115.

37. Ralph, J.; Lundguist, K.; Brunow, G.; Lu, F.; Kim, H.; Schatz, P.F.; Marita, J.M.; Hatfield, R.D.; Ralph, S.A.; Christensen, J.H. Lignins: Natural polymers from oxidative coupling of 4-hydroxyphenyl-propanoids. Phytochem. Rev. 2004, 3, 29-60.

38. Ek, M.; Gellerstedt, G.; Henriksson, G. Wood Chemistry and Wood Biotechnology; Walter de Gruyter: Berlin, Germany, 2009.

39. Kupiec, K.; Konieczka, P. Charakterystyka, procesy chemicznej modyfikacji oraz zastosowanie krzemionki. Ecol. Chem. Eng. 2007, 14, 473-487.

40. Klapiszewski, Ł.; Nowacka, M.; Milczarek, G.; Jesionowski, T. Physicochemical and electrokinetic properties of silica/lignin biocomposites. Carbohydr. Polym. 2013, 94, 345-355.

41. Klapiszewski, L.; Rzemieniecki, T.; Krawczyk, M.; Malina, D.; Norman, M.; Zdarta, J.; Majchrzak, I.; Dobrowolska, A.; Czaczyk, K.; Jesionowski, T. Kraft lignin/silica-AgNPs as a functional material with antibacterial activity. Colloids Surf. B Biointerfaces 2015, 134, 220-228.

42. Ciesielczyk, F.; Klapiszewski, Ł.; Szwarc-Rzepka, K.; Jesionowski, T. A novel method of combination of Kraft lignin with synthetic mineral suport. Adv. Powder Technol. 2014, 25, 695-703.

43. Yamamoto, T.; Yabushita, S.; Irisawa, T.; Tanabe, Y. Enhancement of bending strength, thermal stability and recyclability of carbon-fiber-reinforced thermoplastics by using silica colloids. Compos. Sci. Technol. 2019, 18, 107665.

44. Karunakaran, G.; Suriyaprabha, R.; Manivasakan, P.; Yuvakkumar, R.; Rajendran, V.; Prabu, P.; Kannan, N. Effect of nanosilica and silicon sources on plant growth promoting rhizobacteria, soil nutrients and maize seed germination. IET Nanobiotechnol. 2013, 7, 70-77.

45. Bhatt, B.; Prajapati, V.; Patel, K.; Trivedi, U. Kitchen waste for economical amylase production using Bacillus amyloliquefaciens KCP2. Biocatal. Agric. Biotechnol. 2020, 26, 101654.

46. Mei, J.; Shen, X.; Gang, L.; Xu, H.; Wu, F.; Sheng, L. A novel lignin degradation bacteria-Bacillus amyloliquefaciens SL-7 used to degrade straw lignin efficiently. Bioresour. Technol. 2020, 310, 123445. [PubMed]

47. De Gonzalo, G.; Colpa, D.I.; Habib, M.H.; Fraaije, M.W. Bacterial enzymes involved in lignin degradation. J. Biotechnol. 2016, 236, 110-119.

48. Shaheen, R.; Asgher, M.; Hussain, F.; Bhatti, H.N. Immobilized lignin peroxidase from Ganoderma lucidum ibl-05 with improved dye decolorization and cytotoxicity reduction properties. Int. J. Biol. Macromol. 2017, $103,57-64$.

49. Choromański, P.; Karwowska, E.; Łebkowska, M. The influence of petroleum products on the methane fermentation process. J. Hazard. Mater. 2016, 301, 327-331.

50. Liang, Y.G.; Xu, L.; Bao, J.; Firmin, K.A.; Zong, W. Attapulgite enhances methane production from anaerobic digestion of pig slurry by changing enzyme activities and microbial community. Renew. Energy 2020, 145, 222-232.

51. Chu, H.; Lin, X.; Fujii, T.; Morimoto, S.; Yagi, K.; Hu, J.; Zhang, J. Soil microbial biomass, dehydrogenase activity, bacterial community structure in response to long-term fertilizer management. Soil Biol. Biochem. 2007, 39, 2971-2976. 
52. Phuttaro, C.; Sawatdeenarunat, C.; Surendra, K.C.; Boonsawang, P.; Chaiprapat, S.; Khanal, S.K. Anaerobic digestion of hydrothermally-pretreated lignocellulosic biomass: Influence of pretreatment temperatures, inhibitors and soluble organics on methane yield. Bioresour. Technol. 2019, 284, 128-138.

53. Chen, J.L.; Ortiz, R.; Steele, T.W.J.; Stuckey, D.C. Toxicants inhibiting anaerobic digestion: A review. Biotechnol. Adv. 2014, 32, 1523-1534.

54. Chen, Y.; Cheng, J.J.; Creamer, K.S. Inhibition of anaerobic digestion process: A review. Bioresour. Technol. 2008, 99, 4044-4064.

55. Astals, S.; Nolla-Ardčvol, V.; Mata-Alvarez, J. Anaerobic co-digestion of pig manure and crude glycerol at mesophilic conditions: Biogas and digestate. Bioresour. Technol. 2012, 110, 63-70.

56. Quintas, M.; Guimarães, C.; Baylina, J.; Brandão, T.R.S.; Silva, C.L.M. Multiresponse modelling of the caramelisation reaction. Innov. Food Sci. Emerg. Technol. 2007, 8, 306-315.

57. Witaszek, K.; Pilarska, A.A.; Pilarski, K. Selected methods of vegetable raw material pretreatment used in biogas production. Econom. Environ. 2015, 2, 138-152.

58. Pilarska, A.A. Anaerobic co-digestion of waste wafers from the confectionery production with sewage sludge. Pol. J. Environ. Stud. 2018, 27, 237-245.

59. Han, D.; Lee, C.Y.; Soon, W.; Chang, S.W.; Kim, D.J. Enhanced methane production and wastewater sludge stabilization of a continuous full scale thermal pretreatment and thermophilic anaerobic digestion. Bioresour. Technol. 2017, 245, 1162-1167.

60. Chow, W.L.; Chong, S.; Lim, J.W.; Chan, Y.J.; Chong, M.F.; Tiong, T.J.; Chin, J.K.; Pan, G.T. Anaerobic co-digestion of wastewater sludge: A review of potential co-substrates and operating factors for improved methane yield. Processes 2020, 8, 39-60.

61. Klapiszewski, Ł.; Bartczak, P.; Wysokowski, M.; Jankowska, M.; Kabat, K.; Jesionowski, T. Silica conjugated with kraft lignin and its use as a novel 'green' sorbent for hazardous metal ions removal. Chem. Eng. J. 2015, 260, 684-693.

62. De Oliveira, L.L.; Duarte, I.C.S.; Sakamoto, I.K.; Varesche, M.B.A. Influence of support material on the immobilization of biomass for the degradation of linear alkylbenzene sulfonate in anaerobic reactors. J. Environ. Manag. 2009, 90, 1261-1268.

63. Abbas, Y.; Yun, S.; Wang, Z.; Zhang, Y.; Zhang, X.; Wang, K. Recent advances in bio-based carbon materials for anaerobic digestion: A review. Renew. Sustain. Energy Rev. 2021, 135, 110378.

64. Watanabe, R.; Tada, C.; Baba, Y.; Fukuda, Y.; Nakai, Y. Enhancing methane production during the anaerobic digestion of crude glycerol using Japanese cedar charcoal. Bioresour. Technol. 2013, 150, 387-392.

65. Carrasco, J.; Kovács, K.; Czech, V.; Fodor, F.; Lucena, J.J.; Vértes, A.; Hernandez-Apaolaza, L. Influence of pH, iron source, and $\mathrm{Fe} /$ ligand ratio on iron speciation in lignosulfonate complexes studied using mössbauer spectroscopy. Implications on their fertilizer properties. J. Agric. Food Chem. 2012, 60, 3331-3340.

Publisher's Note: MDPI stays neutral with regard to jurisdictional claims in published maps and institutional affiliations.

(C) 2020 by the authors. Licensee MDPI, Basel, Switzerland. This article is an open access article distributed under the terms and conditions of the Creative Commons Attribution (CC BY) license (http://creativecommons.org/licenses/by/4.0/). 